\title{
Water column oxygen dynamics within the coastal gradient in the northeastern Gulf of Mexico inner shelf
}

\author{
MichaelSantema, Allan J. Clarke, Kevin Speer ${ }^{\#}$ and Markus Huettel*, \\ Florida State University, Department of Earth, Ocean, and Atmospheric Science, \\ Tallahassee, FL, USA \\ ${ }^{\#}$ Florida State University, Geophysical Fluid Dynamics Institute, Tallahassee, FL, USA
}

*corresponding author: mhuettel@fsu.edu, +1 850-645-1394 


\section{$\underline{\text { Abstract }}$}

This study quantified the coastal gradients of salinity, temperature, nutrients, chlorophyll and oxygen along a transect from 5 to $18 \mathrm{~m}$ depth in the northeastern Gulf of Mexico (NEGOM) through measurements of water column profiles over 4.5-years andrecordings of probes mounted at $0.5 \mathrm{~m}$ above the seafloor over 2-years. The main goal was to determine the influences of the coastal gradients on water column oxygen concentration distributions.Apalachicola River discharge affected the study region as reflected in low-salinity surface layers. Decreasing rates of oxygen production and consumption from the shallowest station to the deepest station were attributed tomeasured coastal gradients of nutrients and the decreasing influence of seafloor processes with increasing distance from shore. Water column photosynthetic oxygen production at a realistic irradiance of $200 \mu \mathrm{E} \mathrm{m}^{-2} \mathrm{~s}^{-1}$ ranged from 0.5 to $4.5 \mathrm{mmol} \mathrm{O}_{2} \mathrm{~m}^{-3}$ $\mathrm{h}^{-1}$, and dark consumption rates from 0.2 to $2.6 \mathrm{mmol} \mathrm{O}_{2} \mathrm{~m}^{-3} \mathrm{~h}^{-1}$. Based on July irradiance profiles and associated production and consumption rates, the water column in July 2009 produced $0.9(1 \mathrm{SD}=0.2) \mathrm{g} \mathrm{C} \mathrm{m}^{-2} \mathrm{~d}^{-1}$ with rates remaining relatively constant over the length of this coastal transect. Benthic boundary layer production reaching $26 \%$ to $43 \%$ of the surface layer production underlines the role of the benthic boundary layer for production in the inner shelf. Oxygen in the benthic boundary layer never decreased below 73\% air saturation, and hypoxic zones, as reported from shelf areas west of the study region, did not occur.Oxygen production exceeded consumption suggesting anet autotrophic system. 


\title{
Keywords
}

Oxygen, coastal gradient, primary production, benthic respiration,West Florida Shelf, Northeastern Gulf.

\author{
$\underline{\text { Abbreviations }}$ \\ NEGOM $=$ Northeastern Gulf of Mexico \\ $\mathrm{dw} / \mathrm{dw}=$ Dry weight to dry weight ratio \\ PAR $=$ Photosynthetically active radiation \\ Chl= Chlorophyll $a$ \\ $\mathrm{NTU}=$ Nephelometric turbidity units \\ $\mathrm{SD}=1$ Standard deviation
}




\section{$\underline{\text { 1. Introduction }}$}

Understanding the oxygen dynamics and controls of production and consumption processes in the coastal zone is central for assessing the functioning of the shelf in the cycles of matter and for identifying trends that may indicate fundamental changes in the ecosystem(Canfield et al., 1993; Glud, 2008). Oxygen is an indicator of the fate of carbon and carbon flux, of system metabolism in a changing climate, and a respondent to external forcing functions. Oxygen thus is also an important indicator of ecosystem health, e.g. coastal eutrophication fueled by riverine runoff of fertilizers and the burning of fossil fuels caused an exponential spread of coastal hypoxic zones since the 1960s(Diaz and Rosenberg, 2008). Oxygen concentrations determine the ability of an ecosystem to sustain fisheries or whether harmfulsulfides may be produced. Bottom waters are of particular interest in terms of oxygen because the settlement of decaying plankton can cause high oxygen consumption rates at the seafloor, a process that is most pronounced in upwelling areas and coastal waters prone to planktonic blooms resulting from eutrophication (Lohrenz et al. 1997, Rabalais et al. 1996).Understanding the current drivers of oxygen dynamics thereforecanenable us to identify and quantify other anthropogenic influences in the future as those that may result fromocean warming, increases in carbon dioxide, changes in nutrient discharge to the ocean or catastrophic events(McQuatters-Gollop et al., 2009). A key requirement for the evaluation of change in oxygen and its magnitude is the availability of baseline data that can be used as reference(Duarte et al., 2009). In light of the recent major crude oil spill in the northern Gulf in 2010, it has become apparent that a record of baseline oxygen dynamics in this coastal region did not exist. Here we present results of a long-term study that focused on 
water column and boundary layer oxygen dynamics in the coastal gradient of the northeastern Gulf of Mexico (NEGOM) inner shelf.

The NEGOM, which includes the northern section of the West Florida Shelf (Fig. 1), is a shallow, broad continental margin and about $300 \mathrm{~km}$ wide at Florida's Big Bend coast(Weisberg et al., 2005). Little information is available on the processes that affect oxygen in the shelf waters of the NEGOM,in contrast to the well-studied northwestern Gulf of Mexico, where the Mississippi outflow causes large oxygen fluctuations and coastal hypoxic zones (Rabalais et al., 2007; Rabalais et al., 2002; Turner et al., 2006). The NEGOM is influenced by the Apalachicola River, the largest riverin Florida, which drains a watershed of approximately $50000 \mathrm{~km}^{2}$, including the Atlanta metropolitan area, and discharges 140 to $>5000 \mathrm{~m}^{3} \mathrm{~s}^{-1}$ into the Gulf of Mexico(Livingston, 2000). Occasionally Mississippi River water moves eastward and can affect the NEGOM and West Florida Shelf (He and Weisberg, 2002b). Currents in the NEGOM shelf are driven mainly by tidal forces and wind(Marmorino, 1983a, b), and during fall and winter, southeasterly winds produce downwelling, while in spring and summer, the wind regime is predominantly northwesterly favoring upwelling(He and Weisberg, 2002a). River discharge and upwelling supply nutrients to the NEGOM shelf, and the ensuing algal bloomscan periodically extend from the Big Bend region far into the eastern Gulf of Mexico (Gilbes et al., 2002; Morey et al., 2009). Nonetheless, the reported water column primary productivity rates south of this study region on theWest Florida Shelf are relatively low, as reflected in oxygen production ratesranging from 0.02 to $0.21 \mathrm{mmol}$ $\mathrm{O}_{2} \mathrm{ml}^{-3} \mathrm{~h}^{-1}$ (Vargo et al., 1987; Wanninkhof et al., 1997). 
This study was initiated to address the lack of oxygen concentration data and information on oxygen dynamics in the inner shelf of the NEGOM. The main goal of this work was to determine the influences of the coastal gradients (in salinity, temperature, nutrients, chlorophyll) on water column oxygen concentration distributions, because so far, the dynamics of oxygen in the NEGOM and the factors influencing these dynamics were poorly quantified. Oxygen measurements in the water column were conductedover 4.5-years, and over 2-years at $0.5 \mathrm{~m}$ above the seafloor to determine magnitudes and the spatial and temporal changes of dissolved oxygen along a transect from the nearshore( 3.7 $\mathrm{km}$ off shore, $5 \mathrm{~m}$ water depth) to $29 \mathrm{~km}$ offshore (18 $\mathrm{m}$ depth). Ourresults provide baseline data for future studies in the NEGOM,a region anticipating rapid coastal development.

\section{$\underline{\text { 2. Methods }}$}

\subsection{Study transect}

Our measurements were conducted along a transect in the NEGOM extending 29 $\mathrm{km}$ in a southeastern direction from the coast off St. Teresa, FL, to K-Tower, a retired US Air Force tower that now is used as a hydrographic and meteorological measurement station (Fig. 1; White et al., 2011). The transect was located approximately $50 \mathrm{~km}$ east of the mouth of Apalachicola River thatdischarges into Apalachicola Bay, an estuary enclosed by barrier islands. Due to this proximity, the Apalachicola River and Bay waters influenced the water composition at the transect. During the study period (2007-2011), the average nutrient concentrations in the bay were $11.8(1 \mathrm{SD}=12.1) \mu \mathrm{moll}^{-1}$ inorganic 
nitrogen, $0.15(1 \mathrm{SD}=0.10) \mu \mathrm{mol} 1^{-1}$ orthophosphate, and $21.5(1 \mathrm{SD}=12.5) \mu \mathrm{mol} \mathrm{l}^{-1}$ silicic acid (Apalachicola National Estuarine Research

Reserve,http://cdmo.baruch.sc.edu/get/landing.cfm).

Insert Figure 1 here

The sediment in this region is composed of mostly quartz sands with some shell hash, and sediment organic carbon content is $<0.1 \%(\mathrm{dw} / \mathrm{dw})$. Five stations, named Station A (5 m water depth), Station ab (7 m), B (10 m), Station bc (15 m), and Station C $(18 \mathrm{~m})$ were established on the transect line, along which the water depth increased almost linearly (Fig. 1). Station A, the station closest to the shore, was protected from the open Gulf by a barrier island on the southwest side (Dog Island), and a shallow sand reef on the southeast side (Dog Island Reef).

The water column profiles ofsalinity, temperature, turbidity, chlorophyll $a$ (via fluorometry), and dissolved oxygen (via fluorometry)were measured nearly monthlywith a YSI 6600 multi-parameter probe at all stations (weather permitting) from 4 April 2007 to 21 September 2011 for 31 samplingtrips(White et al., 2011). The probe was mounted in a cage, lowered to the bottom and raised to the surface, while collecting data at 1second intervals. The data were binned within $1 \mathrm{~m}$ depth intervals.

Discrete water samples were taken, weather permitting, almost every month from 22 July 2008 to 15 September 2010 (14 samples from Station A, 12 from Station B, and 
11 from Station C).Water samplesfor profiles after July 2008 were collected along with the data collection from the multi-parameter probes. Water for oxygen production and consumption measurements was collected using Niskin bottles or buckets (near-surface only) from 0.5 and $4.5 \mathrm{~m}$ water depth for Station A; $0.5,5$, and $9.5 \mathrm{~m}$ for Station B; and 0.5, 9, and 17.5 m depth for Station C. For one study year (August 2007 to August 2008), surface water $(0-1 \mathrm{~m})$ was collected for nutrient analysis (dissolved inorganic nitrogen (DIN), nitrate+nitrite $\left(\mathrm{NO}_{\mathrm{x}}\right)$, ammonium $\left(\mathrm{NH}_{4}{ }^{+}\right)$, phosphate $\left(\mathrm{PO}_{4}{ }^{3-}\right)$, silicic acid $\left.\left(\mathrm{Si}(\mathrm{OH})_{4}\right)\right)$ via colorimetric methods described in Grasshoff et al. (1999). On 11 January 2008 , nutrient samples were also collected from the boundary layer $(0.5 \mathrm{~m}$ above seafloor) at Station C.

YSI multi-probes of the same type as used for the water column were deployed in bottom mounts from 12 March 2008 to 6 January 2011 at Station A, 19 June 2008 to 10 October 2010 at Station B (with a gap between 19 January 2009 and 4 July 2010 because of electrical problems), and 12 March 2008 to 9 November 2010 at Station C to assess potential influences of the sediment on water column oxygen dynamics. The sensors of the multi-parameter probe took measurements at $0.5 \mathrm{~m}$ above the sea floor at $15 \mathrm{~min}$ intervals. Irradiance intensity was measured at the same height above the sedimentas photosynthetically active radiation (PAR) with a $\mathrm{LICOR}^{\circledR}$ planar PAR sensor pointing straight up. Wiper mechanisms kept the sensing surfaces of the oxygen, chlorophyll and PAR sensors clean of settling sediment. The multi-parameter probes were retrieved monthly for cleaning and data downloading. Bad weather delaying service, damage to instruments, and biofouling interfered with data collection, leading to gaps in the time series.Data were flagged as compromised or missing when 1) the probe's supply voltage 
dropped below recommended values, 2) the calibration data were outside acceptable bounds, or 3) when data showed unrealistic temporal changes or negative values.

\subsection{Production and Consumption}

Oxygen production and consumption measurementsof the water samples were started within a few hours after sample collection in an environmental chamber set toinsitu temperature and a full spectrum irradiance intensity of $200 \mu \mathrm{E} \mathrm{m}^{-2} \mathrm{~s}^{-1}(\mathrm{PAR})$. This intensity was chosen to represent arealistic irradiance intensity reaching the boundary layer at all three stations on a sunny summer day and was determined with irradiance profiles and moored PAR sensors (Table 2).AHach ${ }^{\circledR}$ Rugged LDO1001 oxygen optodewas mounted in the neck of each of the glass bottles containing the water samples for theproduction and consumption measurements. The probe was programmed to record the oxygen concentration at 5 min intervals. The water was kept well-mixed with a stirring magnet during the entire incubation. Three bottles were incubated for each station and water depth (bottom, mid, or surface).Net primary production values were derived from oxygen change over time. Oxygen consumption rates were measured in the same setup under dark conditions.

Production rates were measured over a range of different irradiance intensitiesto assess the potential range of photosynthetic oxygen production for the irradiance intensities occurring during the day. Because we did not isolate the primary producers, but measured whole community metabolism, our laboratory tests produced community irradiance response curves that differ from standard PI-curves because they are affected by heterotrophic organisms.For these measurements, water samples from bottom, mid, 
and surface water were collected in triplicate from each of the 3 main stations once in July 2011. The water samples were incubated in $1 \mathrm{~L}$ glass bottles as described above and maintained at in situ temperature inside a water bath placed in a sunlit areaoutside. Eight different irradiance intensities were adjusted and maintained for 60 -minute time periods by a stack of black window screensmounted above the bottle setup. Irradiance intensity at the bottles was constantly logged with a LICOR ${ }^{\circledR}$ spherical PAR sensor attached to a LICOR $^{\circledR}$ LI-1400 data logger. Periods of 10 minutes of irradiance exposure were followed by 10 minutes of complete darkness by covering the entire system by a thick opaque tarpaulin. Three periods for each irradiance intensity were averaged to produce values for mean oxygen production. The same was done for the dark periodsto calculate average consumption rates. This dark respiration measured during daytime was not equal to dark respiration during nighttime due to differences in, e.g., photorespiration, cytochrome pathway respiration or the Mehler reaction (Ogren, 1984). The differences caused by these reactions, however, are relatively small (Burris, 1977; Lewitus and Kana, 1995; Lloyd et al., 1977), and we chose the alternating production-respiration measurements during daytime irradiance hours in order to avoid introducingartifactsthat would arise from changes in the plankton community over time.

\subsection{Environmental data}

Irradiance intensities at the water surface weretaken from the nearby Apalachicola National Estuarine Research meteorological station at East Point, FL, at $2947.45^{\prime}$ N, -84 53.00' W (NOAA, 2012); these data are accessible through the National Estuarine Research System (http://cdmo.baruch.sc.edu). Irradiance penetration through the water column was measured at all stations on 28 July 2009 through a PAR sensor (LICOR ${ }^{\circledR}$ ) 
mounted to the CTD lowered from the research vessel from the surface to approximately $1 \mathrm{~m}$ above the seafloor. Wind, cloud cover, and precipitation data collected by NOAA weather data buoy NDBC \#SGOF1 at $29^{\circ} 24.42^{\prime} \mathrm{N}, 8^{\circ} 39.78^{\prime} \mathrm{W}$ (NOAA, 2011) were used to determine meteorological influences on water column conditions. To assess the potential influence of riverine input on production at thestudy transect, we related our primary productivity data to Apalachicola River discharge recorded by the US Geological

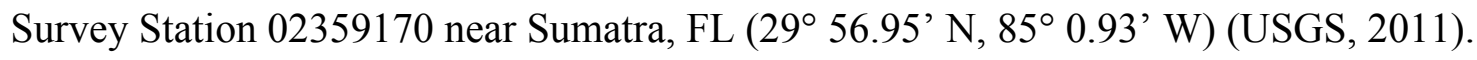

\subsection{Statistical treatment and definition of seasons}

Standard deviations listed reflect one standard deviation and are presented as (1 $\mathrm{SD}=$ value of standard deviation). The significance of the relationship between the variables in linear regressions was tested using F-statistics, and the differences between two regression slopes were tested using t-statistics according to Sachs and Reynarowych (1984). The Kolmogorov-Smirnov test was used to determine whether data sets follow a normal distribution. To test whether two sets of data were significantly different from each other, the t-test was used after testing for normal distribution of the data sets. Where the Kolmogorov-Smirnov test did not indicate normal distribution, we applied the MannWhitney U-test or the Wilcoxon signed-rank test where two related samples were compared (Sachs and Reynarowych, 1984). The $p$-value listed in the statistic test results is the probability of observing an effect, and "df " indicates the degrees of freedom. The significance or alpha $(\alpha)$ level is the probability level for rejection of the null hypothesis, and all tests used an alpha of $0.05(5 \%)$ unless indicated otherwise. We used the winter solstice (Dec. 21/22), vernal equinox (Mar. 20), summer solstice (Jun. 20/21), and 
autumnal equinox (Sep. 22/23) as separators between seasons where seasonal results are reported.

\section{$\underline{\text { 3. Results }}$}

The main characteristics of the water column and sediment are presented in Table 1.The text addresses vertical profiles first, then the changes observed along the transect (lateral gradient), and reports the average trends observed during the 4-year period (spring 2007-spring 2011) unless indicatedotherwise.

The water column in the inner shelf in the NEGOM was characterized by nonhypoxic conditions at all times, warm temperatures, and a low salinity surface layer (0-2 m) with increased chlorophyll concentrations compared to subsurface water $(>2 \mathrm{~m})$ (Wilcoxon test: $p=0.0117, p<0.05$, Fig. 2). Results from statistical testing assessing the significance of the vertical gradients are presented in Table 2A and differences of the gradients between seasons in Table 2B.

Insert Table 1 here

Insert Figure 2 here

Insert Table 2A here

Insert Table 2B here 
The seasonal averages calculated for each station's surface, mid water and bottom layers revealed coastal spatial gradients, reflected in steady changes in major environmental parameters with increasing distance from the shore (Fig. 3, Table 3).

Insert Figure 3 here

Insert Table 3 here

\subsection{Salinity, Temperature and Density}

The salinity profiles typically showed a thin, pronounced surface layer (approximately $2 \mathrm{~m}$ thick) with reduced salinity and then a gradual increase in salinity with depth, except at the most offshore Stations bc and C during winter (Fig. 2). The average water column salinity was lowest in spring (32.8 (1 SD = 2.96)) and steadily increased throughout the year to reach maximum values in winter $(34.4(1 \mathrm{SD}=2.0))$. This trend was most pronounced in the surface layer $(0-1 \mathrm{~m})$, where in spring had an average salinity of $29.6(1 \mathrm{SD}=1.2)$ and then gradually became saltier to reach almost full marine salinity $(33.2(1 \mathrm{SD}=2.5))$ in winter (Fig. 3). A subsurface salinity minimum (decrease by $\sim 1 \mathrm{ppt}$ ) could be observed between 5 and $8 \mathrm{~m}$ water depth at all stations seaward of station ab in summer and fall. Salinity increased with distance from the coast, with the steepest lateral gradient in winter $\left(0.12-0.25 \mathrm{ppt} \mathrm{km}^{-1}\right)$, and the weakest in summer (0.05-0.06 ppt km-1) (Fig. 3). These salinity gradients led to lateral density gradients that were significantly steeper in spring compared to fall (Table 3). 
Water temperatures in fall, winter, and early summer were relatively homogenous over the entire water column depth (Fig. 2). The average winter temperature was 14.4(1 $\mathrm{SD}=0.7)^{\circ} \mathrm{C}$. Seasonal warming in spring produced vertical gradients with increasing temperatures toward the surface, which disappeared in early summer when homogenous warm temperatures $\left(28.8(1 \mathrm{SD}=0.1)^{\circ} \mathrm{C}\right)$ were recorded at all stations and water depths. The wintertime lateral gradient of increasing temperatures towards the ocean reversed during spring, when the shallower waters warmed more rapidly, and became flat during the beginning of summer. Shallow waters cooled more rapidly than deeper water in fall, reinstating a gradient with increasing temperatures toward offshore (Fig. 3).

The water column density profiles were governed by salinity and followed similar trendsas the salinity profiles (Fig. 2). The average water column density decreased from $1025.7(1 \mathrm{SD}=1.5) \mathrm{kg} \mathrm{m}^{-3}$ in winter to $1020.5(1 \mathrm{SD}=2.1) \mathrm{kg} \mathrm{m}^{-3}$ in summer, when the development of steeper lateral density gradients in deeper layers was occasionally observed (e.g., 8 Aug. 2007, 7-9 m: Station B: $4.0 \mathrm{~kg} \mathrm{~m}^{-3} \mathrm{~m}^{-1}$, bc: $2.8 \mathrm{~kg} \mathrm{~m}^{-3} \mathrm{~m}^{-1}$,Station C: $2.3 \mathrm{~g} \mathrm{l}^{-1} \mathrm{~kg} \mathrm{~m}^{-3} \mathrm{~m}^{-1}$, $28 \mathrm{Jul}$ 09: 9-11 m, bc: $9.2 \mathrm{~kg} \mathrm{~m}^{-3} \mathrm{~m}^{-1}$, Station C: $2.3 \mathrm{~kg} \mathrm{~m}^{-3} \mathrm{~m}^{-1}$ ). The lateral water column density gradient weakened between spring $\left(0.10-0.19 \mathrm{~kg} \mathrm{~m}^{-3}\right.$ $\left.\mathrm{km}^{-1}\right)$ and fall $\left(0.02-0.05 \mathrm{~kg} \mathrm{~m}^{-3} \mathrm{~km}^{-1}\right)$.

\subsection{Oxygen}

Oxygen concentrations weretypically highest at the surface reaching up to $118 \%$ air saturation (Station A, 8 Aug. 2007, $228.8 \mathrm{mmol} \mathrm{m}^{-3}$ ) andgenerally showed a relatively steady decline with water depth (Fig. 2, Table 2). The highest average water column oxygen concentrations (102.0(1 SD $=1.4) \%$ saturation) and most homogenous oxygen 
distributions were recorded during winter, while the summer measurements were characterized by the lowest average concentrations $(97.5(1 \mathrm{SD}=3.8) \%)$ and a more rapid decline of oxygen with increasing water depth (Table 2). The lowest oxygen concentrations were recorded at the deeper water Stations bc and C during summer (Fig. 2, minima e.g.: Station bc: 8 Aug. 2007, 79.2\%, $154.6 \mathrm{mmol} \mathrm{m}^{-3}$, Station C: 8 Jun 08, $\left.73.6 \%, 147.3 \mathrm{mmol} \mathrm{m}^{-3}\right)$.

The average surface to bottom oxygen gradient became less steep toward offshore, first rapidly from $-2.3 \mathrm{mmol} \mathrm{m}^{-3} \mathrm{~m}^{-1}$ at Station A to $-1.1 \mathrm{mmol} \mathrm{m}^{-3} \mathrm{~m}^{-1}$ at Station B, and then more gently toward Station bc, reaching $-0.9 \mathrm{mmol} \mathrm{m}^{-3} \mathrm{~m}^{-1}$ at Station C(Fig. 4). The differences in this gradient declinebetween shallower and deeper stations were statistically not significant due to the relatively large variability in the gradient at Station A.

Insert Figure 4 here

The average water column oxygen concentration decreased with distance from shore (Fig. 3, Station A: $100.2(1 \mathrm{SD}=9.9) \%$, Station C: $98.2(1 \mathrm{SD}=6.1) \%)$. This trend was significant in all seasons (Table 3). The average lateral gradients in oxygen saturation steepened significantly between winter and summer, and spring and summer, and became significantly less between summer and fall (Table 3). While the lateral oxygen gradient in the surface layer $(0-1 \mathrm{~m})$ changed by less than $\pm 0.05 \% \mathrm{~km}^{-1}$ throughout the year, the gradient in the benthic boundary layer ( $0.5 \mathrm{~m}$ above seabed) between winter and summer steepened by one order of magnitude (winter: $-0.12 \% \mathrm{~km}^{-1}$, spring: $-0.20 \% \mathrm{~km}^{-1}$, summer 
$\left.-0.41 \% \mathrm{~km}^{-1}\right)$ and in fall rapidly reversed to less than the winter value $\left(-0.04 \% \mathrm{~km}^{-1}\right.$, Fig. 3).

\subsection{Chlorophyll}

The chlorophyllconcentrations in the water columnalong the transect were lowest in spring $\left(0.90(1 \mathrm{SD}=0.81) \mathrm{mgm}^{-3}\right)$ and highest in summer $\left(2.10(1 \mathrm{SD}=1.15) \mathrm{mgm}^{-3}\right)$ and during the study period reached $5 \mathrm{mgm}^{-3}$. At Station A, Chla concentrations increased from the surface to the bottom, and this trend was significant in winter and fall (Fig. 2, Table 2A). At all other stations, Chla concentrations typically showed high concentrations in the surface layer, coinciding with the layer of reduced salinity. Below this layer,Chlaconcentrations decreased to a minimum and then increased again towards the bottom. The highest water column Chla concentrationswere always recorded at the nearshore Station A $\left(3.1(1 \mathrm{SD}=3.8) \mathrm{mgm}^{-3}\right)$, intermediate at Station B $(1.7(1 \mathrm{SD}=$ 5.9) $\left.\mathrm{mgm}^{-3}\right)$ and the lowest offshore at Station $\mathrm{C}\left(0.6(1 \mathrm{SD}=2.0) \mathrm{mgm}^{-3}\right)$. This lateral gradient was most pronounced in the subsurface layers (significant in the boundary layer 0-1 $\mathrm{m}$ above seafloor in winter and summer, Table 3), while the surface layer concentrations showed large variations with no clear lateral trend. The average water column Chla along the transect over time revealed a seasonal pattern with three main concentration peaks over the course of the year, recorded in February/March/April, July, and October/November (Fig. 5).

Insert Figure 5 here 


\subsection{Nutrients}

The nutrient concentrations in the surface water layer $(0-1 \mathrm{~m})$ along the transect were low throughout the study period (Fig. 6, DIN $<1.5 \mathrm{mmol} \mathrm{m}^{-3}, \mathrm{PO}_{4}{ }^{3-}<0.25 \mathrm{mmol} \mathrm{m}^{-}$ ${ }^{3}$ and $\left.\mathrm{Si}(\mathrm{OH})_{4}<8 \mathrm{mmol} \mathrm{m}^{-3}\right)$.

Insert Figure 6 here

Insert Table 4 here

$\mathrm{NH}_{4}{ }^{+}$dominated DIN (contributing $80-91 \%$ of the DIN) and reached $2.4 \mathrm{mmolm}^{-3}$ during summer. The nutrient concentrations from samples collected in January 2008 from the benthic boundary layer were low (DIN: $0.90 \mathrm{mmol} \mathrm{m}^{-3}, \mathrm{NO}_{\mathrm{x}}: 0.01 \mathrm{mmol} \mathrm{m}^{-3}, \mathrm{NH}_{4}^{+}$: $0.89 \mathrm{mmol} \mathrm{m}^{-3}, \mathrm{PO}_{4}{ }^{3-}: 0.08 \mathrm{mmol} \mathrm{m}^{-3}$ and $\left.\mathrm{Si}(\mathrm{OH})_{4}: 0.27 \mathrm{mmol} \mathrm{m}^{-3}\right)$. The seasonal surface water sampling revealed gradients of decreasing $\mathrm{DIN}, \mathrm{PO}_{4}{ }^{3-}$ and $\mathrm{Si}(\mathrm{OH})_{4}$ concentrations from the shore toward offshore during winter, and for $\mathrm{NH}_{4}^{+}$, this gradient was statistically significant (Table 4). Except for $\mathrm{Si}(\mathrm{OH})_{4}$, these trends of decreasing concentration with distance from shore disappeared during spring, when DIN and $\mathrm{PO}_{4}{ }^{3-}$ concentrations were lowest at Station $\mathrm{A}$, and $\mathrm{DIN}$ and $\mathrm{Si}(\mathrm{OH})_{4}$ reached their lowest values during the year. In summer, DIN increased with distance from shore similar to spring, but with a steeper gradient. In contrast, $\mathrm{PO}_{4}{ }^{3-}$ and $\mathrm{Si}(\mathrm{OH})_{4}$ in summer declined toward offshore. The summer trends of DIN, $\mathrm{PO}_{4}{ }^{3-}$ and $\mathrm{Si}(\mathrm{OH})_{4}$ were statistically significant (Table 4). These $\mathrm{PO}_{4}{ }^{3-}$ and $\mathrm{Si}(\mathrm{OH})_{4}$ gradients persisted with similar magnitudes in fall, while the lateral DIN gradient 
disappeared during this season. N/P ratios along the transect ranged from 4 to 20 . The data suggest a decrease in N/P from winter $(16.8(1 \mathrm{SD}=3.5))$ to fall $(8.1(1 \mathrm{SD}=$ 3.2))and an increase ofN/P with distance from shore, but these trends were statistically not significant (Table 4)

\subsection{Production and consumption rate measurements}

The irradiance profiles recorded at the stations in July 2009 showed exponential light intensity decay with water depth at all stations with attenuation coefficients ranging from $0.68(1 \mathrm{SD}=0.28) \mathrm{m}^{-1}$ at Station B to $0.43(1 \mathrm{SD}=0.33) \mathrm{m}^{-1}$ at Station C (Fig. 7).

Insert Figure 7 here

On the sunny day in July 2009, when the light intensity profiles were measured, the average PAR levels ranged from 250 to $850 \mu \mathrm{E} \mathrm{m}^{-2} \mathrm{~s}^{-1}$ in the surface layer $(0-1 \mathrm{~m})$ and $64 \mu \mathrm{E} \mathrm{m}^{-2} \mathrm{~s}^{-1}$ to $355 \mu \mathrm{E} \mathrm{m}^{-2} \mathrm{~s}^{-1}$ in the boundary layer ( $0.5 \mathrm{~m}$ above sediment) at Stations A and C, respectively.The oxygen gross production rates measured at a realistic in-situ irradiance of $200 \mu \mathrm{E} \mathrm{m}^{-2} \mathrm{~s}^{-1}$ in the water sampled along the transect ranged from 0.5 to $4.5 \mathrm{mmol} \mathrm{O}_{2} \mathrm{~m}^{-3} \mathrm{~h}^{-1}$, and the dark consumption rates from 0.2 to $2.6 \mathrm{mmol} \mathrm{O}_{2} \mathrm{~m}^{-3} \mathrm{~h}^{-}$

${ }^{1}$. For the same irradianceof $200 \mu \mathrm{E} \mathrm{m}^{-2} \mathrm{~s}^{-1}$, both production and consumption were higher in the bottom boundary layer compared to those in the surface layer (Fig. 8,Wilcoxon test: production $\mathrm{n}=12, p=0.0047, p<0.05$, consumption $\mathrm{n}=12, p=0.0029, p<0.05$ ). Figure 8 suggests trends of oxygen production and consumption increase with depth and 
decrease with distance from shore, but these trends are not statistically significant because of the variability of the data.

Annual production averaged over the water column exceeded annual consumption by a factor of $2.0(1 \mathrm{SD}=0.4)$, with higher values in winter and summer and the lowest ratio in fall (1.5) (Fig. 9). The production to consumption ratios (Production/Respiration ratios, $\mathrm{P} / \mathrm{R}$ ) between the seasons were not statistically different and the annual $\mathrm{P} / \mathrm{R}$ ratios did not differ significantly between surface layer $(1.8(1 \mathrm{SD}=0.3))$ and boundary layer $(1.7(1 \mathrm{SD}=0.1))$.

Insert Figure 8 here

Insert Figure 9 here

The measurements of potential rates of water column oxygen productionthrough incubation of water samples at different irradiance intensitiesrevealed an increase of the average water column oxygen production by $1.43(1 \mathrm{SD}=0.01) \mu \mathrm{mol} \mathrm{m}^{-3} \mathrm{~s}^{-1}$ per $1000 \mu \mathrm{E}$ $\mathrm{m}^{-2} \mathrm{~s}^{-1}$ irradiance increase with no significant differences between stations (Fig. 10).

Insert Figure 10 here 


\section{Discussion}

\subsection{Water column characteristics}

The water column along the transect in the NEGOM showed typical characteristics of a subtropical inner shelf environment in a humid climate, with coastal freshwater input producing a thin $(<2 \mathrm{~m})$ surface water layer with lower salinity and density overlying an otherwise relatively well mixed water columnthroughout the year (Fig. 2) (Sharples, 1997). Mixing of the freshwater into deeper layers along the transect resulted in a lateral gradient with a less saline water column near the coast and higher salinity offshore (Fig. 3). The Apalachicola River discharge typically reaches its highest rates during February and March and lowest rates in August (Fig. 1), also typical of a subtropical coastal environment (Piola et al., 2000).As a result, the lateral salinity gradient was steepest in winter and spring, and least developed in summer(Fig. 3).The subsurface salinity minimum observed at Stations $\mathrm{B}$, bc and $\mathrm{C}$ between spring and fall is attributed to either sinking of less saline and at times slightly colder surface water,currents bringing in another water mass,or a mixing event.The data do not reveal where this low salinity water mass originated.

The water column average temperature response to seasonal irradiation changes decreased with water depth. Vertical mixing caused fairly homogenous temperatures throughout the water column except during spring, when temperature in the deeper water layers trailed behind the rapid temperature increase in the surface layer, resulting in the steepest vertical temperature gradients recorded during all seasons (Fig. 2). Similarly, cooling in fall and winter was more rapid at the shallower stations, in contrast to spring, 
where no pronounced vertical gradients were observed.Cooling from the surface and increased wave action during fall resulted in stronger water column mixing than in the spring (NOAA, 2011 wave heights:

http://www.ndbc.noaa.gov/view_climplot.php?station=42036\&meas=wh).

\subsection{Oxygen}

Oxygen profiles showed little influence of density stratification, but rather direct and indirect effects of temperature, mixing by waves and currents, and biological activity. The relatively steady oxygen decrease between surface and bottom layer (Fig. 2) suggest that mid-water column processes had less influence on oxygen distribution, and that exchange with the atmosphere and photosynthetic production in the surface layer, and respiration processes in the bottom boundary layer and seafloor governed the vertical concentration gradient.Manickchand-Heileman et al.(1998)concluded from a massbalance trophic model for the continental shelf of the southwestern Gulf of Mexico that only about $10 \%$ of primary production is consumed in the water column, which supportsthis hypothesis. The scaling of primary production and benthic respiration with irradiation and temperature produced the most pronounced surface to bottom oxygen gradients during summer $\left(-0.82(1 \mathrm{SD}=0.18) \% \mathrm{~m}^{-1}\right)$ and the most uniform water column oxygen distribution during winter $\left(-0.23(1 \mathrm{SD}=0.12) \% \mathrm{~m}^{-1}\right)$. This quadrupling of the vertical gradients between winter and summer rapidly reversed in fall due to dropping water column temperatures (Fig. 2).

High biological activity throughout the water column combined with decreasing water depth caused a steepening of the vertical oxygen profiles toward the coast. The 
mixing by waves and currents was not strong enough to eliminate these gradients. Increasing bottom water currents nearing the shore, mainly caused by waves, enhanced exchange between seabed and water column and thereby also benthic production and consumption. The average depth of the wave base at the stations (Fig. 1), determined from ADCP data (Maksimova and Clarke, 2013), suggest that waves had negligible influence on the seafloor at Station C (depth of wave base $\approx$ station depth), moderate influence at Station B (wave base depth $\approx 1.6 *$ station depth) and strong influence at Station $\mathrm{A}$ (wave base $\approx 2 *$ station depth) (Fig. 1). Where wave orbital motion reaches the seafloor, it causes pore water exchange in the permeable sands that dominate this study region (Precht and Huettel, 2003, 2004; Wiberg and Harris, 1994), enhancing oxygen production and consumption through advective transport of organic matter and oxygen into the sediment and the release of anoxic pore waters and photosynthetic oxygen from the bed (Huettel et al., 2014; Huettel et al., 2003). This is supported by measurements of oxygen fluxes in a sandy sublittoral area at the mouth of West Falmouth Harbor (Massachusetts) with the non-invasive eddy correlation technique (i.e. a technique that does not affect the flow and light conditions at the sediment surface) that revealed a strong correlation between bottom currents and oxygen flux (Berg et al., 2013). Photosynthesis of marine benthic autotrophs is correlated to water flow through theenhancement of transport of oxygen, carbon dioxide and nutrients at the algal cells (Berninger and Huettel, 1997; Cook and Roy, 2006; Koch, 1994; Mass et al., 2010). On the other hand, the flow-induced pore water exchange can substantially boost benthic respiration as shown in flume experiments by Forster et al. (1996), who reported a 91\% increase in total oxygen uptake in permeable sediments with a $11 \mathrm{~cm} \mathrm{~s}^{-1}$ increase of 
flowunder dark conditions. The declining oxygen concentrations approaching the sediment surface we recorded during daylight conditions indicate that benthic respiration occurred at a higher rate than benthic production along the transect.

Our data suggest that surface to bottom oxygen gradients steepened by one order of magnitude when water depth became shallower than $8 \mathrm{~m}$ (Fig. 4, gradient change rate Stations A $\rightarrow$ B: $0.12 \mathrm{mmol} \mathrm{m}^{-3} \mathrm{~m}^{-1} \mathrm{~km}^{-1}$ vs. Stations $\left.\mathrm{B} \rightarrow \mathrm{C}: 0.01 \mathrm{mmol} \mathrm{m}^{-3} \mathrm{~m}^{-1} \mathrm{~km}^{-1}\right)$, however, because of the limited number of stations, this change is not statistically supported. Such an increase can be caused by frequent sediment resuspension produced by surface waves at the shallow Stations A and ab. At these stations, the average wave orbital motion at the seafloor exceeded $20 \mathrm{~cm} \mathrm{~s}^{-1}$, the threshold for sediment erosion and resuspension. The latter was shown to cause substantial increases in respiration rates (Almroth et al., 2009; Almroth-Rosell et al., 2012).

Mortenson (2013)suggests that under calm conditions, oxygen concentrationsalong the transect could also be influenced by tidal water exchange (using Fourier analysis), but we could not detect relationships between tide and any of the other parameters measured at the stations.

The generally higheroxygen concentrations near the shore (up to $118 \%$ saturation at Station A, in Aug. 2007)are attributed to the higher photosynthetic oxygen productionin this zone boosted by terrestrial nutrient input and stronger mixing.Dissolved inorganic nitrogen (DIN) concentrations in the Apalachicola Bay outflow were about one order of magnitude higher than the DIN concentrations measured along the transect in the surface water, which contained most of the freshwater input throughout the year (Fig. 6). 
Nevertheless, the low salinity surface layer usually was associated with high chlorophyll concentrations (Fig. 2), suggesting that nutrients in the freshwater component supported phytoplankton growth. This hypothesis is backed by observations by Gilbes et al. (1996) and Morey et al. (2009),who reported that satellite images show a plume of enhanced surface layer chlorophyll along the West Florida Shelf during phases of high Apalachicola River discharge. Current models show that this plume can be pushed into this study area (Morey et al., 2003; Weisberg et al., 2005).

Bay water and coastal runoff produced a lateral concentration gradient of inorganic nitrogen and phosphorus that became apparent during winter, when primary productivity was lowest (Fig. 6). The winter N/P ratios averaged 17 and, thus, were close to theRedfield ratio. Despite maximum nutrient-rich freshwater input in February/March (Fig. 1), the coastal nutrient gradients largely disappeared during spring and concentrations reached their annual, minima suggesting high usageand possibly nutrient limitation. This hypothesis is supported by spring N/P ratios of 13 despite phosphate concentrations $<0.1 \mathrm{mmol} \mathrm{m}^{-3}$ and Apalachicola Bay N/P of 62. During summer,there was a steep lateral gradient of N/P from 5 at Station A to 17 at Station C $\left(0.5 \mathrm{~km}^{-1}\right)$ underlining high $\mathrm{N}$ usage and possibly $\mathrm{N}$ limitation at the shallowest stations despite the coastal $\mathrm{N}$-input. The lateral gradient of $\mathrm{N}$ increasing offshore withPO ${ }_{4}{ }^{3-}$ and $\mathrm{Si}(\mathrm{OH})_{4}$ decreasing offshore supports that $\mathrm{N}$ was aheavily consumed nutrient in nearshore stations and possibly a limiting factor.

The relatively high correlation $\left(\mathrm{r}^{2}=0.6\right.$ to 0.9$)$ between oxygen and chlorophyll content suggests that local phytoplankton dominated the generation of oxygen and was at least indirectly responsible for oxygen consumption in the water column (Fig. 11). 
Insert Figure 11 here.

Oxygen and chlorophyll concentrations were positively correlated in the upper water layer (0-3 m), except at Station A. Below the upper water layer, this trend reversed and oxygen concentrations decreased with increasing chlorophyll concentrations (Fig. 11). Oxygen concentration at Station A was negatively correlated to chlorophyll concentration throughout the water column likely because of the strong mixing at Station A and the relatively stronger oxygen consumption in the lower layers compared to the production in the upper water layers. Besides this exception, the increase of oxygen concentration with increasing chlorophyll concentration in the upper water column appeared strongest near the coast and less pronounced offshore, while oxygen concentration decrease with increasing chlorophyll concentration in the lower layers grew with increasing distance from the shore (difference of slope test between bc and $\mathrm{C}$ in winter: $\mathrm{t}=-2.3865, \mathrm{df}=19, p=0.0276, p<0.05$, in summer: $\mathrm{t}=-13.8541, \mathrm{df}=19, p=$ $2.2 \mathrm{E}-11, p<0.05)$. The decreasing availability of light and nutrients averaged over the water column promoted respiration relative to oxygen production with increasing distance from shore. These lateral trends were most pronounced during summer, when higher irradiation and associated temperature increase enhanced production as well as oxygen consumption processes.

The water column thus goes through seasonal oxygen concentrationoscillations that have the largest amplitude in the benthic boundary layer, where the lateral 
oxygenconcentration gradient steepened by one order of magnitude between winter and summer (winter: $-0.04 \% \mathrm{~m}^{-3} \mathrm{~km}^{-1}$, summer: $-0.41 \% \mathrm{~m}^{-3} \mathrm{~km}^{-1}$ ). In this layer, the lowest oxygen concentrations observed during the study were measured and coincided with Chlaconcentrationmaxima near the bottom (August 8, 2007: 79.2\%, $154.6 \mathrm{mmol} \mathrm{m}^{-3}$, August 6, 2008: 73.6\%, 147.3mmol m${ }^{-3}$, July 28, 2009: 79.1\%, $160.2 \mathrm{mmol} \mathrm{m}^{-3}$, July 13, 2011: $74.96 \%, 147.28 \mathrm{mmol} \mathrm{m}^{-3}$ ). The oxygen concentrations thus never became a limiting factor for aerobic life (Claireaux et al., 2000; Craig and Crowder, 2005).

\subsection{Primary productivity}

Our measured production/respiration $\operatorname{ratios}(\mathrm{P} / \mathrm{R}$, average $=2)$ suggest that the water column in this area is net autotrophic, i.e., more oxygen and organic matter is produced than consumed. Sporadically high rates of oxygen consumption in the fall, regardless of oxygen production rates, led to a low correlation $\left(\mathrm{R}^{2}=0.48\right)$ for that season. (Fig. 9).At anirradiance of $600 \mu \mathrm{E} \mathrm{m}^{-2} \mathrm{~s}^{-1}$, water column gross production along thetransect at all stations and depths wason average2.8 $(1 \mathrm{SD}=1.3) \mathrm{mmol} \mathrm{O}_{2} \mathrm{~m}^{-3} \mathrm{~h}^{-1}$.Our photosynthesis rates, at both a relatively low irradiance intensity $\left(0\right.$ to $1.7 \mathrm{mmol} \mathrm{O}_{2} \mathrm{~m}^{-3} \mathrm{~h}^{-}$ ${ }^{1}$ at $\left.100 \mu \mathrm{E} \mathrm{m}^{-2} \mathrm{~s}^{-1}\right)$ and saturating irradiance intensity $\left(0.7\right.$ to $7.5 \mathrm{mmol} \mathrm{O}_{2} \mathrm{~m}^{-3} \mathrm{~h}^{-1}$ at 1000 $\mu \mathrm{E} \mathrm{m}^{-2} \mathrm{~s}^{-1}$ ), were statistically not different from rates reported from estuarine and coastal Gulf of Mexico environments (Murrell et al., 2009, Yates et al. 2007, Del Castillo et al. 2000, Mortazavi et al. 2000, Table 5), but significantly higher (U-test, $p<0.05$ ) than reported for outer shelf regions in the Gulf (Chen et al. 2000, Wanninkhof et al. 1997, Vargo et al. 1987, Hitchcock et al. 2000, Table 5) or subtropical regions of similar distance from shore from the Pacific Ocean (Aguirre-Hernández et al., 2004). 
Insert Table 5 here

Our values were very similar to those measured by Del Castillo et al. (2000) (0.33-1.63 mmol O $\mathrm{O}^{-3} \mathrm{~h}^{-1}$ ), which were measured relatively close to thetransect (at $29.6 \mathrm{~N}, 85.1 \mathrm{~W}$ $\sim 60 \mathrm{~km}$ west), and larger than those reported by Hitchcock et al. (2000) (0.28-0.38 mmol $\mathrm{O}_{2} \mathrm{~m}^{-3} \mathrm{~h}^{-1}$ ), observed about $50 \mathrm{~km}$ south of thisstudy region. Walsh et al. (2003) reported a phytoplankton primary production of $1.8 \mathrm{~g} \mathrm{C} \mathrm{m}^{-2} \mathrm{~d}^{-1}$ along the $40-\mathrm{m}$ isobath farther south in this region and increasing oxygen production and consumption rates with decreasing water depth. Using the light profiles we measured along thetransect in July and the production and respiration rates determined for July water exposed to different irradiation rates, we obtain water column primary production rates of 0.6 to $1.2 \mathrm{~g} \mathrm{C} \mathrm{m}^{-2}$ $\mathrm{d}^{-1}$ (Fig. 12). Plotting production rates for surface, mid water and boundary water layers indicated that production in each layer increased toward the coast, with the boundary layer reaching approximately $26 \%$ (offshore Station C) to $43 \%$ (nearshore Station A) of the surface layer production. This increase toward the shore partly compensated the effect of decreasing water depth on total water column production, so that the latter remained relatively constant $\left(0.9(1 \mathrm{SD}=0.2) \mathrm{g} \mathrm{C} \mathrm{m}^{-2} \mathrm{~d}^{-1}\right)$ over the length of the coastal transect.

Insert Figure 12 here 
The Louisiana coastal shelf, influenced by the Mississippi and Atchafalaya Rivers, may have experienced primary production rates $\left(3.5(1 \mathrm{SD}=2.1) \mathrm{g} \mathrm{C} \mathrm{m}^{-2} \mathrm{~d}^{-1}\right.$; Quigg et al., 2011) three times greater than those we found in the summer. The inner shelf area we investigated, which was influenced by the Apalachicola River discharge and coastal runoff, had rates that were more than double those reported from oligotrophic subtropical and tropical environments (Burford et al., 2012; Jiang et al., 2011; Webster et al., 2002). We identifythis area as upper meso- to eutrophic, followingNixon's (1995) classification, who defined coastal areas with production rates $>300 \mathrm{~g} \mathrm{C} \mathrm{m}^{-2} \mathrm{y}^{-1}\left(0.8 \mathrm{~g} \mathrm{C} \mathrm{m}^{-}\right.$ $\left.{ }^{2} \mathrm{~d}^{-1}\right)$ as eutrophic.

Manmade activities that cause high nutrient concentrations in rivers threaten coastal waters and shelf ecosystems (Bianchi et al., 2013; Galloway et al., 1995; Seitzinger et al., 2005). As a consequence, coastal hypoxic zones are increasing worldwide, and are now considered one of the most severe threats to marine ecosystems (Diaz and Rosenberg, 2008). One of the largest river-induced hypoxic zones occurs annually in the northwestern Gulf of Mexico, where the Mississippi River releases nutrients into the shelf. The oxygen dynamics of this region have been the subject of numerous studies (Bianchi et al. 2010, Rabalais et al., 2007, Rabalais et al., 2004; Rabalais et al., 2002; Turner and Rabalais, 1994). In contrast, very little information is available for the coast east of the Mississippi Delta, and the NEGOM that is affected by the Apalachicola River discharge. We did not find any indications of hypoxia at our site but the rapid coastal development and population growth in the Apalachicola River watershed and on the Florida Panhandle coast may lead to an increase in nutrient 
discharge and organic matter to the coast. Monitoring the oxygen dynamics in the NEGOM can provide warning signs for a deterioration of the system.

\subsection{Conclusions}

This study provides a long-term data set characterizing the coastal gradient of key environmental variables in the inner shelf400 $\mathrm{km}$ east of the Mississippi Delta, with emphasis on the spatial and temporal dynamics of water column oxygen. The transect data reflect the influence of theenergy maximum in the coastal zone (Huettel et al. 2014), with enhanced production at the shallow sites characterized by increasedterrestrial nutrient input, irradiation reaching the sediment, and wave mixing. The vertical and horizontal gradients measured along the transect emphasized the role of the seafloor as a major factor influencing oxygen dynamics in the coastal water column. The time series indicated that the inner NEGOM shelf is anautotrophic environment with relatively high oxygen concentrations that never dropped to levels that could affect aerobic lifeforms. With the consistent patterns in the vertical and horizontal gradients this study quantified, it provides baseline data that can be used to quantify long-term trends in the NEGOM. 


\section{Acknowledgements}

We thank Sonja Bridges, Alison Ma, Joel Valdez, and Van Vandermeullenfrom the FSU Marine and Coastal Laboratory Academic Diving Program, our boat captains Roseanne Weglinski and Mike Lavendar. Eric Howarth and Stephanie White of the FSU Current Meter Facilityhelped with the maintenance and deployment of the YSI multiprobes. Chiu Cheng, Dr. Lindsay Chipman, Chris Hagen, John Kaba, Matt Laschet, Dr. Cedric Magen, Lee Russell, Brian Wells, Dr. Rich Wildman, Veronica Cruz, Stacia Dudley, Ian Hunter, and Matt Smithhelped with laboratory measurements. Also, thanks for help interpreting data toDr. Ekaterina Maksimova-Lobodina, Eric Mortenson, and Dr. Athena Rycyk. Finally, we would like to thank all the volunteers that helped with sample collection. This research was funded by NOAA NGI grant 023320, NSF projectsOCE424967,OCE-536431, and OCE-726754, and by the Geophysical Fluid Dynamics Institute at FSU. 


\section{$\underline{\text { References }}$}

Aguirre-Hernández, E., Gaxiola-Castro, G., Nájera-Martínez, S., Baumgartner, T., Kahru, M., Mitchell, B.G., 2004. Phytoplankton absorption, photosynthetic parameters, and primary production off Baja California: Summer and autumn 1998. Deep-Sea Research II 51, 799-816.

Almroth, E., Tengberg, A., Andersson, J.H., Pakhomova, S., Hall, P.O.J., 2009. Effects of resuspension on benthic fluxes of oxygen, nutrients, dissolved inorganic carbon, iron and manganese in the Gulf of Finland, Baltic Sea. Continental Shelf Research 29, 807-818.

Almroth-Rosell, E., Tengberg, A., Andersson, S., Apler, A., Hall, P.O.J., 2012. Effects of simulated natural and massive resuspension on benthic oxygen, nutrient and dissolved inorganic carbon fluxes in Loch Creran, Scotland. Journal of Sea Research 72, 38-48.

Berg, P., Long, M.H., Huettel, M., Rheuban, J.E., McGlathery, K.J., Howarth, R.W., Foreman, K.H., Giblin, A.E., Marino, R., 2013. Eddy correlation measurements of oxygen fluxes in permeable sediments exposed to varying current flow and light. Limnol. Oceanogr. 58, 1329-1343.

Berninger, U.G., Huettel, M., 1997. Impact of flow on oxygen dynamics in photosynthetically active sediments. Aquatic Microbial Ecology 12, 291-302.

Bianchi, T.S., Allison, M.A., Cai, W.J., 2013. An introduction to the biogeochemistry of river-coastal systems, in: Bianchi, T.S., Allison, M.A., Cai, W.J. (Eds.), Biogeochemical Dynamics at Major River-coastal Interfaces: Linkages with Global Change. Cambridge University Press, New York, pp. 3-20. 
Bianchi, T.S., DiMarco, S.F., Cowan, J.H., Hetland, R.D., Chapman, P., Day, J.W., Allison, M.A., 2010. The science of hypoxia in the Northern Gulf of Mexico: A review. Science of the Total Environment 408, 1471-1484.

Burford, M.A., Revill, A.T., Smith, J., Clementson, L., 2012. Effect of sewage nutrients on algal production, biomass and pigments in tropical tidal creeks. Marine Pollution Bulletin 64, 2671-2680.

Burris, J.E., 1977. Photosynthesis, photorespiration, and dark respiration in 8 species of algae. Marine Biology 39, 371-379.

Canfield, D.E., Jørgensen, B.B., Fossing, H., Glud, R., Gundersen, J., Ramsing, N.B., Thamdrup, B., Hansen, J.W., Nielsen, L.P., Hall, P.O.J., 1993. Pathways of organic carbon oxidation in three continental margin sediments. Marine Geology $113,27-40$.

Chen, X., Lohrenz, S.E., Wiesenburg, D.A., 2000. Distribution and controlling mechanisms of primary production on the Louisiana-Texas continental shelf. Journal of Marine Systems 25, 179-207.

Claireaux, G., Webber, D.M., Lagardère, J.P., Kerr, S.R., 2000. Influence of water temperature and oxygenation on the aerobic metabolic scope of Atlantic cod (Gadus morhua). Journal of Sea Research 44, 257-265.

Cook, P.L.M., Roy, H., 2006. Advective relief of CO2 limitation in microphytobenthos in highly productive sandy sediments. Limnol. Oceanogr. 51, 1594-1601.

Craig, J.K., Crowder, L.B., 2005. Hypoxia-induced habitat shifts and energetic consequences in Atlantic croaker and brown shrimp on the Gulf of Mexico shelf. Marine Ecology Progress Series 294, 79-94. 
Daneri, G., Lizarraga, L., Montero, P., Gonzalez, H.E., Tapia, F.J., 2012. Wind forcing and short-term variability of phytoplankton and heterotrophic bacterioplankton in the coastal zone of the Concepcion upwelling system (Central Chile). Progress in Oceanography 92-95, 92-96.

Dean, R.G., Dalrymple, R.A., 1991. Water wave mechanics for engineers and scientists. World Scientific, Singapore.

Del Castillo, C.E., Gilbes, F., Coble, P.G., Muller-Karger, F.E., 2000. On the dispersal of riverine colored dissolved organic matter over the West Florida Shelf. Limnology andOceanography $45,1425-1432$.

Diaz, R.J., Rosenberg, R., 2008. Spreading dead zones and consequences for marine ecosystems. Science 321, 926-929.

Duarte, C.M., Conley, D.J., Carstensen, J., Sanchez-Camacho, M., 2009. Return to Neverland: Shifting Baselines Affect Eutrophication Restoration Targets. Estuaries and Coasts 32, 29-36.

Forster, S., Huettel, M., Ziebis, W., 1996. Impact of boundary layer flow velocity on oxygen utilisation in coastal sediments. Marine Ecology Progress Series 146, 173185.

Galloway, J.N., Schlesinger, W.H., II, H.L., Michaels, A., Schnoo, J.L., 1995. Nitrogen fixation: Anthropogenic enhancement-environmental response Global Biogeochemical Cycles 9, 235-252.

Gilbes, F., Muller-Karger, F.E., Del Castillo, C.E., 2002. New evidence for the West Florida Shelf plume. Continental Shelf Research 22, 2479-2496. 
Gilbes, F., Tomas, C., Walsh, J.J., MullerKarger, F.E., 1996. An episodic chlorophyll plume on the West Florida Shelf. Continental Shelf Research 16, 1201-1224.

Glud, R.N., 2008. Oxygen dynamics of marine sediments. Marine Biology Research 4, 243-289.

Grasshoff, K., Klaus Kremling, K., Ehrhardt, M., 1999. Methods of Seawater Analysis, 3rd Edition. John Wiley and Sons.

Gubelit, Y.I., Berezina, N.A., 2010. The causes and consequences of algal blooms: the Cladophora glomerata bloom and the Neva estuary (eastern Baltic Sea). Marine Pollution Bulletin 61, 183-188.

Gutierrez-Rodriguez, A., Latasa, M., Scharek, R., Massana, R., Vila, G., Gasol, J.M., 2011. Growth and grazing rate dynamics of major phytoplankton groups in an oligotrophic coastal site. Estuarine, Coastal \& Shelf Science 95, 77-87.

Hargrave, B.T., Prouse, N.J., Phillips, G.A., Neame, P.A., 1983. Primary production and respiration in pelagic and benthic communities at two intertidal sites in the upper Bay of Fundy. Canadian Journal of Fisheries and Aquatic Sciences 40, 229-243.

He, R., Weisberg, R.H., 2002a. West Florida shelf circulation and temperature budget for the 1999 spring transition. Continental Shelf Research 22, 719-748.

He, R.Y., Weisberg, A.H., 2002b. Tides on the West Florida shelf. Journal of Physical Oceanography 32, 3455-3473.

Hitchcock, G., Vargo, G.A., Dickson, M.-L., 2000. Plankton community composition, production, and respiration in relation to dissolved inorganic carbon on the West Florida Shelf, April 1996. Journal of Geophysical Research 105, 6579-6589. 
Huettel, M., Berg, P., Kostka, J.E., 2014. Benthic exchange and biogeochemical cycling in permeable sediments. Annual Review of Marine Science, Vol 6 6, 23-51.

Huettel, M., Røy, H., Precht, E., Ehrenhauss, S., 2003. Hydrodynamical impact on biogeochemical processes in aquatic sediments. Hydrobiologia 494, 231-236.

Jiang, Z.-P., Huang, J.-C., Dai, M., Kao, S.J., Hydes, D.J., Chou, W.-C., Jan, S., 2011. Short-term dynamics of oxygen and carbon in productive nearshore shallow seawater systems off Taiwan: Observations and modeling. Limnology andOceanography 56, 1832-1849.

Koch, E.W., 1994. hydrodynamics, diffusion-boundary layers and photosynthesis of the seagrasses Thalassia testudinum and Cymodocea nodosa. Marine Biology 118, 767-776.

Krause-Jensen, D., Markager, S., Dalsgaard, T., 2012. Benthic and pelagic primary production in different nutrient regimes. Estuaries and Coasts 35, 527-545.

Lewitus, A.J., Kana, T.M., 1995. Light respiration in 6 estuarine phytoplankton species contrasts under photoautotrophic and mixotrophic growth-conditions. Journal of Phycology 31, 754-761.

Livingston, R.J., 2000. Eutrophication Processes in Coastal Systems: Origin and Succession of Plankton Blooms and Effects on Secondary Production. CRC.

Lloyd, N.D.H., Canvin, D.T., Culver, D.A., 1977. Photosynthesis and photorespiration in algae. Plant Physiology 59, 936-940.

Lohrenz, S.E., Fahnenstiel, G.L., Redalje, D.G., Lang, G.A., Chen, X.G., Dagg, M.J., 1997. Variations in primary production of northern Gulf of Mexico continental 
shelf waters linked to nutrient inputs from the Mississippi River. Marine Ecology Progress Series 155, 45-54.

Maksimova, E.V., Clarke, A.J., 2013. Multiyear subinertial and seasonal Eulerian current observations near the Florida Big Bend coast. Journal of Physical Oceanography 43, 1691-1709.

Manickchand-Heileman, S., Soto, L.A., Escobar, E., 1998. A preliminary trophic model of the continental shelf, south-western Gulf of Mexico. Estuarine Coastal and Shelf Science 46, 885-899.

Marmorino, G.O., 1983a. Summertime coastal currents in the northeastern Gulf of Mexico. Journal of Physical Oceanography 13, 65-77.

Marmorino, G.O., 1983b. Variability of current, temperature, and bottom pressure across the West Florida continental-shelf, Winter 1981-1982. Journal of Geophysical Research-Oceans and Atmospheres 88, 4439-4457.

Mass, T., Genin, A., Shavit, U., Grinstein, M., Tchernov, D., 2010. Flow enhances photosynthesis in marine benthic autotrophs by increasing the efflux of oxygen from the organism to the water. PNAS 107, 2527-2531.

McQuatters-Gollop, A., Gilbert, A.J., Mee, L.D., Vermaat, J.E., Artioli, Y., Humborg, C., Wulff, F., 2009. How well do ecosystem indicators communicate the effects of anthropogenic eutrophication? Estuarine Coastal and Shelf Science 82, 583-596.

Morey, S.L., Dukhovskoy, D.S., Bourassa, M.A., 2009. Connectivity of the Apalachicola River flow variability and the physical and bio-optical oceanic properties of the northern West Florida Shelf. Continental Shelf Research 29, 1264-1275. 
Morey, S.L., Schroeder, W.W., O'Brien, J.J., Zavala-Hidalgo, J., 2003. The annual cycle of riverine influence in the eastern Gulf of Mexico basin. Geophysical Research Letters 30. 1867-1870.

Mortazavi, B., Iverson, R., Landing, W., Lewis, F.G., Huang, W., 2000. Control of phytoplankton production and biomass in a river-dominated estuary: Apalchicola Bay, Florida, USA. Marine Ecology Progress Series 198, 19-31.

Mortenson, E., 2013. Physical description and analysis of the variability ofsalinity and oxygen in Apalachicola Bay, Department of Earth, Ocean, and Atmospheric Sciences. Florida State University, Tallahassee, FL, p. 65.

Murrell, M.C., Campbell, J.G., James D. Hagy, I., Caffrey, J.M., 2009. Effects of irradiance on benthic and water column processes in a Gulf of Mexico estuary: Pensacola Bay, Florida, USA. Estuarine, Coastal and Shelf Science 81, 501-512.

Nixon, S.W., 1995. Coastal marine eutrophication - a definition, social causes, and future concerns. Ophelia 41, 199-219.

NOAA, 2011. National Data Buoy Center, Stennis Space Center, MS.Retrieved 9 Aug, 2011, from http://www.ndbc.noaa.gov/.

NOAA, 2012. National Estuarine Research Reserve System Centralized Data Management Office. Retrieved 19 Dec, 2012, from http://cdmo.baruch.sc.edu.

Ogren, W.L., 1984. Photorespiration: pathways, regulation, and modification. Plant Physiology 35, 415-442.

Piola, A.R., Campos, E.J.D., Möller, O.O., Charo, M., Martinez, C., 2000. Subtropical shelf front off Eastern South America. Journal of Geophysical Research 105, 6565-6578. 
Precht, E., Huettel, M., 2003. Advective pore-water exchange driven by surface gravity waves and its ecological implications. Limnology andOceanography. 48, 16741684.

Precht, E., Huettel, M., 2004. Rapid wave-driven advective pore water exchange in a permeable coastal sediment. Journal of Sea Research 51, 93-107.

Quigg, A., Sylvan, J.B., Gustafson, A.B., Fisher, T.R., Oliver, R.L., Tozzi, S., Ammerman, J.W., 2011. Going West: nutrient limitation of primary production in the Northern Gulf of Mexico and the importance of the Atchafalaya River. Aquatic Geochemistry 17, 519-544.

Rabalais, N.N., Atilla, N., Normandeau, C., Turner, R.E., 2004. Ecosystem history of Mississippi River-influenced continental shelf revealed through preserved phytoplankton pigments. Marine Pollution Bulletin 49, 537-547.

Rabalais, N.N., Turner, R.E., Sen Gupta, B.K., Boesch, D.F., Chapman, P., Murrell, M.C., 2007. Hypoxia in the Northern Gulf of Mexico: does the science support the plan to reduce, mitigate, and control hypoxia? Estuaries and Coasts 30, 753772.

Rabalais, N.N., Turner, R.E., Wiseman, W.J., 2002. Gulf of Mexico hypoxia, aka "The dead zone". Annual Review of Ecology and Systematics 33, 235-263.

Sachs, L., Reynarowych, Z., 1984. Applied Statistics: A Handbook of Techniques. Springer.

Sallon, A., Michel, C., Gosselin, M., 2011. Summertime primary production and carbon export in the southeastern Beaufort Sea during the low ice year of 2008. Polar Biology 34, 1989-2005. 
Seitzinger, S.P., Harrison, J.A., Dumont, E., Beusen, A.H.W., Bouwman, A.F., 2005. Sources and delivery of carbon, nitrogen, and phosphorus to the coastal zone: an overview of global nutrient export from watersheds (NEWS) models and their application. Global Biogeochemical Cycles 19.

Sharples, J., 1997. Cross-shelf intrusion of subtropical water into the coastal zone of northeast New Zealand. Continental Shelf Research 17, 835-857.

Turner, R.E., Rabalais, N.N., 1994. Coastal eutrophication near the Mississippi River Delta. Nature 368, 619-621.

Turner, R.E., Rabalais, N.N., Justic, D., 2006. Predicting summer hypoxia in the northern Gulf of Mexico: Riverine N, P, and Si loading. Marine Pollution Bulletin 52, 139148.

USGS, 2011. USGS Real-Time Water Data for the Nation. Retrieved 9 Aug, 2011, from http://waterdata.usgs.gov/usa/nwis/uv?site_no $=02359170$.

Vargo, G.A., Carder, K.L., Gregg, W., Shanley, E., Heil, C., Steidinger, K.A., Haddad, K.D., 1987. The potential contribution of primary production by red tides to the West Florida Shelf ecosystem. Limnology andOceanography 32, 762-767.

Walsh, J.J., Weisberg, R.H., Dieterle, D.A., He, R.Y., Darrow, B.P., Jolliff, J.K., Lester, K.M., Vargo, G.A., Kirkpatrick, G.J., Fanning, K.A., Sutton, T.T., Jochens, A.E., Biggs, D.C., Nababan, B., Hu, C.M., Muller-Karger, F.E., 2003. Phytoplankton response to intrusions of slope water on the West Florida Shelf: models and observations. J. Geophys. Res. 108.

Wanninkhof, R., Hitchcock, G., Wiseman, W.J., Vargo, G.A., Ortner, P.B., Asher, W., Ho, D.T., Schlosser, P., Dickson, M.-L., Masserini, R., Fanning, K., Zhang, J.-Z., 
1997. Gas exchange, dispersion, and biological productivity on the west Florida shelf: Results from a Lagrangian tracer study. Geophysical Research Letters 24, $1767-1770$.

Webster, I.T., Ford, P.W., Hodgson, B., 2002. Microphytobenthos contribution to nutrient-phytoplankton dynamics in a shallow coastal lagoon. Estuaries 25, 540551.

Weisberg, R., H., He, R.L., Y., Virmani, J.I., 2005. West Florida Shelf circulation on synoptic, seasonal, and interannual time scales.Circulation in the Gulf of Mexico: Observations and Models. AGU, pp. 325-347

White, S., Speer, K., Huettel, M., 2011. Marine Field Group Technical Report: Physical Observations in the Florida State University Northern Gulf Institute Program: Hydrographic Sections and Fixed Sites June 2009-June 2011. Florida State University, Tallahassee, FL, USA.

Wiberg, P.L., Harris, C.K., 1994. Ripple geometry in wave-dominated environments. Journal of Geophysical Research - Oceans 99, 775-789.

Williams, P.J.1.B., 1998. The balance of plankton respiration and photosynthesis in the open oceans.Nature 394, 55-57. 
$\underline{\text { Tables }}$

Table 1. Characteristics of the sediments and water columnalong the study transect.

\begin{tabular}{|c|c|c|c|c|c|c|c|c|c|c|c|}
\hline ation & $\begin{array}{c}\text { Depth } \\
(\mathrm{m})\end{array}$ & Latitude & Longitude & $\begin{array}{l}\text { Median } \\
\text { grain } \\
\text { size } \\
(\mu \mathrm{m})\end{array}$ & $\begin{array}{c}\text { Salinity } \\
\text { (ppt) }\end{array}$ & $\begin{array}{l}\text { Temp. } \\
\left({ }^{\circ} \mathrm{C}\right)\end{array}$ & $\begin{array}{l}\text { Density } \\
\left(\mathrm{kg} \mathrm{m}^{-3}\right)\end{array}$ & $\begin{array}{c}\mathrm{O}_{2} \\
(\mu \mathrm{mol} \mathrm{I}-1)\end{array}$ & $\begin{array}{c}\mathrm{Chl} \mathrm{a} \\
\left(\mathrm{mg} \mathrm{m}^{-3}\right)\end{array}$ & $\begin{array}{c}\text { Turbidity } \\
\text { (NTU) }\end{array}$ & $\begin{array}{l}\text { Daily max. light } \\
\text { at } 0.5 \mathrm{~m} \text { above } \\
\text { seafloor } \\
\left(\mathrm{PAR} \mu \mathrm{E} \mathrm{m}^{-2} \mathrm{~s}^{-1}\right)\end{array}$ \\
\hline A & 5 & $29^{\circ} 51.50^{\prime} \mathrm{N}$ & $84^{\circ} 31.50^{\prime} \mathrm{W}$ & 269 & $0.5-37$ & $11-31$ & $997-1028$ & $177-265$ & $0.1-12.3$ & $0.3-3.5$ & $0.4-448$ \\
\hline$a b$ & 7 & $29^{\circ} 48.00^{\prime} \mathrm{N}$ & $84^{\circ} 31.00^{\prime} \mathrm{W}$ & & $5-37$ & $11-30$ & $1001-1027$ & $200-249$ & $0.1-20.5$ & $0.3-3.0$ & \\
\hline B & 10 & $29^{\circ} 47.67^{\prime} \mathrm{N}$ & $84^{\circ} 28.33^{\prime} \mathrm{W}$ & 313 & $5-37$ & $11-30$ & $1001-1026$ & $213-242$ & $0.1-115$ & $0.3-2.8$ & $1.4-317$ \\
\hline$b c$ & 15 & $29^{\circ} 43.80^{\prime} \mathrm{N}$ & $84^{\circ} 25.15^{\prime} \mathrm{W}$ & & $0.8-36$ & $11-31$ & $997-1027$ & $193-240$ & $0.1-3.2$ & $0.3-2.7$ & \\
\hline C & 18 & $29^{\circ} 39.90^{\prime} \mathrm{N}$ & $84^{\circ} 22.29^{\prime} \mathrm{W}$ & 428 & $1-36$ & $17-30$ & $997-1027$ & $168-235$ & $0.1-29$ & $0.3-2.9$ & $1-267$ \\
\hline
\end{tabular}


Table 2 A. Slopes of the vertical gradients of salinity, temperature, density, oxygen and chlorophyll for the four seasons. Grey text identifies slopes that are statistically not significant $(\mathrm{p}>0.05)$. Chl.S lists values for the subsurface chlorophyll profiles $(>2 \mathrm{~m}$ depth), i.e. the profiles below the chlorophyll subsurface minimum.

\begin{tabular}{|c|c|c|c|c|c|c|c|c|c|c|c|c|}
\hline \multirow[b]{2}{*}{ Parameter } & \multicolumn{3}{|c|}{ Winter } & \multicolumn{3}{|c|}{ Spring } & \multicolumn{3}{|c|}{ Summer } & \multicolumn{3}{|c|}{ Fall } \\
\hline & lope & $\mathbf{r}^{2}$ & $p$ & Slope & $\mathbf{r}^{2}$ & $p$ & Slope & $r^{2}$ & $p$ & Slope & $r^{2}$ & $p$ \\
\hline & \multicolumn{12}{|c|}{ Station A } \\
\hline Sal. (ppt) & 0.759 & 0.921 & 9.6E-03 & 0.511 & 0.207 & 4.4E-01 & 1.454 & 0.887 & 1.7E-02 & 0.754 & 0.654 & . $8 \mathrm{E}-02$ \\
\hline Temp. $\left({ }^{\circ} \mathrm{C}\right)$ & 0.110 & 0.822 & $3.4 \mathrm{E}-02$ & -0.104 & 0.605 & 1.2E-01 & 0.087 & 0.514 & 1.7E-01 & -0.065 & 0.860 & 2.3E-02 \\
\hline Dens. $\left(\mathrm{kg} \mathrm{m}^{-3}\right)$ & 0.616 & 0.921 & $9.6 \mathrm{E}-03$ & 0.414 & 0.250 & 3.9E-01 & 1.072 & 0.895 & $1.5 \mathrm{E}-02$ & 0.611 & 0.659 & 9.5E-02 \\
\hline $\mathrm{O} 2\left(\mu \mathrm{mol} \mathrm{I}{ }^{-1}\right)$ & -1.615 & 0.908 & 1.2E-02 & -0.956 & 0.117 & 5.7E-01 & -4.049 & 0.965 & $2.8 \mathrm{E}-03$ & -1.883 & 0.759 & 5.4E-02 \\
\hline O2 (\% air sat.) & 0.361 & .723 & $6.8 \mathrm{E}-02$ & -0.318 & 0.245 & 4.0E-01 & -1.051 & 0.900 & $1.4 \mathrm{E}-02$ & -0.474 & 0.767 & 5.1E-02 \\
\hline Chl. $\left(\mathrm{mg} \mathrm{m}^{-3}\right)$ & 0.304 & 0.892 & 1.6E-02 & 0.287 & 0.745 & 5.9E-02 & 0.491 & 0.878 & $1.9 \mathrm{E}-02$ & 0.250 & 0.973 & 1.9E-03 \\
\hline \multirow[t]{2}{*}{ Chl.S (mg m $\left.{ }^{-3}\right)$} & .457 & 998 & 2.1E-04 & 0.176 & 0.197 & $6.5 \mathrm{E}-01$ & 0.563 & 0.823 & 1.2E-01 & 0.275 & 0.944 & $2.6 \mathrm{E}-02$ \\
\hline & \multicolumn{12}{|c|}{ Station ab } \\
\hline Sal. (ppt) & 0.558 & 0.756 & $2.9 \mathrm{E}-02$ & 0.762 & 0.793 & $2.2 \mathrm{E}-02$ & 0.618 & 0.541 & 9.3E-02 & 0.234 & 0.966 & 1.3E-03 \\
\hline Temp. $\left({ }^{\circ} \mathrm{C}\right)$ & 0.016 & 0.159 & 4.0E-01 & -0.072 & 0.546 & $9.2 \mathrm{E}-02$ & -0.003 & 0.005 & 8.9E-01 & 0.019 & 0.130 & 4.5E-01 \\
\hline Dens. $\left(\mathrm{kg} \mathrm{m}^{-3}\right)$ & 0.429 & 0.752 & 3.0E-02 & & 0.823 & & & & 8.2E-02 & & 0.779 & $2.5 E-02$ \\
\hline $\mathrm{O} 2\left(\mu \mathrm{mol} \mathrm{I}{ }^{-1}\right)$ & -1.935 & 0.907 & $6.1 \mathrm{E}-03$ & -1.083 & 0.680 & 4.7E-02 & -2.095 & 0.912 & 5.5E-03 & -0.739 & 0.819 & $1.8 \mathrm{E}-02$ \\
\hline $\mathrm{O} 2$ (\% air sat.) & -0.340 & 0.926 & 4.2E-03 & -0.170 & 0.869 & 1.0E-02 & -0.711 & 0.987 & 2.9E-04 & -0.144 & 0.687 & 4.5E-02 \\
\hline Chl. $\left(\mathrm{mg} \mathrm{m}^{-3}\right)$ & 0.101 & 0.450 & 1.4E-01 & -0.154 & 0.816 & $1.8 \mathrm{E}-02$ & -0.087 & 0.366 & 1.9E-01 & -0.007 & 0.002 & 9.3E-01 \\
\hline \multirow[t]{2}{*}{ Chl.S $\left(\mathrm{mg} \mathrm{m}^{-3}\right)$} & .204 & 0.926 & 8.8E-03 & -0.092 & 0.508 & $1.8 \mathrm{E}-01$ & 0.018 & 0.036 & 7.6E-01 & 0.126 & 0.737 & 6.3E-02 \\
\hline & \multicolumn{12}{|c|}{ Station B } \\
\hline Sal. (ppt) & 0.234 & 0.895 & 3.7E-03 & 0.385 & 0.400 & 1.0E-01 & 0.262 & 0.298 & 1.6E-01 & 0.296 & 0.524 & 5.9E-02 \\
\hline Temp. $\left({ }^{\circ} \mathrm{C}\right)$ & -0.008 & 0.337 & 1.4E-01 & -0.163 & 0.693 & $2.4 \mathrm{E}-02$ & -0.025 & 0.506 & 6.4E-02 & 0.052 & 0.934 & $1.8 \mathrm{E}-03$ \\
\hline Dens. $\left(\mathrm{kg} \mathrm{m}^{-3}\right)$ & 0.195 & 0.902 & $3.3 E-03$ & 0.375 & 0.431 & $9.1 \mathrm{E}-02$ & 0.222 & 0.364 & 1.2E-01 & 0.226 & 0.525 & 5.9E-02 \\
\hline $\mathrm{O} 2(\mu \mathrm{mc}$ & 5 & 954 & 1.0E-03 & & 0.918 & 2.5 & -1.294 & 0.909 & 2.9E-03 & -1.382 & 0.909 & 2.9E-03 \\
\hline O2 (\% air sat.) & -0.378 & 0.947 & 1.3E-03 & -0.302 & 0.985 & 1.8 & -0.545 & 0.984 & 2.0E-04 & -0.341 & 0.963 & 7.2E-04 \\
\hline Chl. $\left(\mathrm{mg} \mathrm{m}^{-3}\right)$ & 0.026 & 0.075 & 4.8E-01 & -0.029 & 0.050 & 5.6E-01 & 0.113 & 0.543 & 5.4E-02 & -0.078 & 0.448 & 8.4E-02 \\
\hline \multirow[t]{2}{*}{ Chl.S (mg m $\left.{ }^{-3}\right)$} & 102 & .861 & 1.1E-02 & 0.074 & 0.813 & 1.9E-02 & 0.178 & 0.944 & 2.7E-03 & -0.034 & 0.630 & $6.2 \mathrm{E}-02$ \\
\hline & \multicolumn{12}{|c|}{ Station bc } \\
\hline Sal. (ppt) & 0.103 & 0.976 & $1.8 \mathrm{E}-04$ & 0.234 & 0.535 & 3.1E-02 & 0.322 & 0.846 & $3.5 E-03$ & 0.115 & 0.288 & 1.1E-01 \\
\hline Temp. $\left({ }^{\circ} \mathrm{C}\right)$ & 0.002 & 0.095 & 3.3E-01 & -0.084 & 0.948 & $6.0 \mathrm{E}-04$ & -0.013 & 0.690 & $1.3 \mathrm{E}-02$ & 0.008 & 0.382 & 6.6E-02 \\
\hline Dens. $\left(\mathrm{kg} \mathrm{m}^{-3}\right)$ & 0.091 & 0.980 & 1.3E-04 & 0.210 & 0.633 & $1.8 \mathrm{E}-02$ & 0.261 & 0.866 & 2.7E-03 & 0.098 & 0.340 & 8.1E-02 \\
\hline $\mathrm{O} 2\left(\mu \mathrm{mol} \mathrm{I}{ }^{-1}\right)$ & -0.741 & 0.976 & $1.8 \mathrm{E}-04$ & -0.757 & 0.894 & 1.9E-03 & -1.923 & 0.971 & $2.4 \mathrm{E}-04$ & -0.539 & 0.827 & 4.3E-03 \\
\hline O2 (\% air sat.) & -0.222 & 0.979 & $1.5 E-04$ & & 0.972 & $2.2 \mathrm{E}-04$ & -0.813 & 0.964 & $3.4 \mathrm{E}-04$ & -0.158 & 0.973 & 2.1E-04 \\
\hline Chl. $\left(\mathrm{mg} \mathrm{m}^{-3}\right)$ & 0.026 & 0.335 & 8.3E-02 & -0.019 & 0.048 & 4.8E-01 & 0.137 & 0.956 & 4.6E-04 & 0.032 & 0.671 & 1.4E-02 \\
\hline \multirow[t]{2}{*}{ Chl.S (mg m$\left.{ }^{-3}\right)$} & .042 & 0.833 & 5.1E-03 & 0.027 & 0.802 & 6.9E-03 & 0.152 & 0.973 & 2.7E-04 & 0.032 & 0.722 & 1.3E-02 \\
\hline & \multicolumn{12}{|c|}{ Station C } \\
\hline Sal. (ppt) & 0.047 & 0.898 & $1.3 \mathrm{E}-03$ & 0.163 & 0.498 & 2.8E-02 & 0.141 & 0.221 & 1.2E-01 & 0.092 & 0.228 & 1.2E-01 \\
\hline Temp. $\left({ }^{\circ} \mathrm{C}\right)$ & 0.009 & 0.803 & 4.0E-03 & -0.097 & 0.962 & 2.7E-04 & -0.024 & 0.702 & 8.7E-03 & -0.003 & 0.202 & 1.4E-01 \\
\hline Dens. $\left(\mathrm{kg} \mathrm{m}^{-3}\right)$ & 0.046 & 0.925 & $7.8 \mathrm{E}-04$ & 0.161 & 0.630 & $1.4 \mathrm{E}-02$ & 0.135 & 0.304 & 7.7E-02 & 0.083 & 0.299 & 7.9E-02 \\
\hline $\mathrm{O} 2\left(\mu \mathrm{mol} \mathrm{I}^{-1}\right)$ & -0.647 & 0.990 & 3.3E-05 & -0.678 & 0.946 & 4.6E-04 & -1.727 & 0.943 & $5.0 \mathrm{E}-04$ & -0.590 & 0.795 & 4.3E-03 \\
\hline O2 (\% air sat.) & -0.211 & 0.991 & 3.1E-05 & -0.383 & 0.963 & $2.6 \mathrm{E}-04$ & -0.829 & 0.960 & 2.9E-04 & -0.219 & 0.975 & $1.4 \mathrm{E}-04$ \\
\hline Chl. $\left(\mathrm{mg} \mathrm{m}^{-3}\right)$ & -0.013 & 0.015 & $6.5 E-01$ & -0.016 & 0.077 & 3.3E-01 & -0.025 & 0.045 & 4.5E-01 & -0.014 & 0.056 & 4.0E-01 \\
\hline Chl.S $\left(\mathrm{mg} \mathrm{m}^{-3}\right)$ & 0.045 & 0.934 & $7.8 \mathrm{E}-04$ & 0.015 & 0.813 & 4.4E-03 & 0.027 & 0.195 & 1.6E-01 & 0.012 & 0.491 & $3.5 \mathrm{E}-02$ \\
\hline
\end{tabular}


Table 2 B. Statistical comparisons of the vertical gradients (slopes) for the measured water column parameters between seasons using t-statistics. Black numbers indicate significant differences in the slope between the two seasons listed in the respective column label $(p<0.05)$.Ch. S indicates $p$-values for the subsurface chlorophyll gradient changes between seasons.

\begin{tabular}{|c|c|c|c|c|c|c|}
\hline r & $\begin{array}{c}\text { Winter } \\
\text { Spring } \\
p\end{array}$ & $\begin{array}{c}\text { Winter } \\
\text { Summer } \\
p\end{array}$ & $\begin{array}{c}\text { Winter } \\
\text { Fall } \\
p\end{array}$ & $\begin{array}{c}\text { Spring } \\
\text { Summer } \\
p\end{array}$ & $\begin{array}{c}\text { Spring } \\
\text { Fall } \\
p\end{array}$ & $\begin{array}{c}\text { Summer } \\
\text { Fall } \\
p\end{array}$ \\
\hline \multicolumn{7}{|c|}{ Station A } \\
\hline Sal. (ppt) & $6.9 \mathrm{E}-01$ & 7.7E-02 & 9.9E-01 & 2.0E-01 & 7.2E-01 & 1.6E-01 \\
\hline Temp. $\left({ }^{\circ} \mathrm{C}\right)$ & $1 E-01$ & 1.3E-02 & $2.2 \mathrm{E}-01$ & $3.2 \mathrm{E}=02$ & 4.7E-01 & $2.5 \mathrm{E}-02$ \\
\hline Dens. $\left(\mathrm{kg} \mathrm{m}^{-3}\right)$ & $6.5 E-01$ & 1.0E-01 & $9.9 \mathrm{E}-01$ & 2.1E-01 & 7.0E-01 & 2.1E-01 \\
\hline $\mathrm{O}_{2}\left(\mu \mathrm{mol} \mathrm{I} \mathrm{I}^{-1}\right)$ & $9.1 \mathrm{E}-01$ & $2.8 \mathrm{E}-02$ & $5.9 E-01$ & $1.0 \mathrm{E}-01$ & 6.7E-01 & $6.3 \mathrm{E}-02$ \\
\hline $\mathrm{O}_{2}$ (\% air sat.) & 1.7E-01 & 3.9E-03 & 7.1E-01 & 8.6E-04 & 2.4E-01 & 2.9E-02 \\
\hline Chl. $\left(\mathrm{mg} \mathrm{m}^{-3}\right)$ & $8.9 \mathrm{E}-01$ & 1.8E-01 & 4.4E-01 & $2.0 \mathrm{E}-01$ & 7.2E-01 & $6.8 \mathrm{E}-02$ \\
\hline Chl.S ( $\left.\mathrm{mg} \mathrm{m}^{-3}\right)$ & 1E-01 & -01 & 1.2E-01 & 4.7E-01 & 8.1E-01 & 4.0E-01 \\
\hline \multicolumn{7}{|c|}{ Station ab } \\
\hline & 3.8E-01 & 8.4E-01 & $5.9 \mathrm{E}-01$ & 6.5E-01 & $9.8 \mathrm{E}-01$ & 7.5E-01 \\
\hline Temp & 2.6E-02 & 4.7E-01 & 6.9E-03 & 7.8E-02 & 8.3E-01 & 3.6E-02 \\
\hline Dens $(k a m$ & 3.5E-01 & 7.8E-01 & 5.3E-01 & 6.8E-01 & 9.4E-01 & $7.2 \mathrm{E}-01$ \\
\hline $\mathrm{O}_{2}\left(\mu \mathrm{mol} \mathrm{I} \mathrm{I}^{-1}\right)$ & $8.5 E-03$ & $6.1 \mathrm{E}-05$ & 4.2E-01 & $4.2 \mathrm{E}-07$ & 8.3E-02 & 1.7E-01 \\
\hline $\mathrm{O}_{2}$ (\% air sat.) & $1.4 \mathrm{E}-03$ & 7.0E-01 & $9.4 \mathrm{E}-01$ & 8.1E-04 & $9.2 \mathrm{E}-02$ & 7.6E-01 \\
\hline Chl. $\left(\mathrm{mg} \mathrm{m}^{-3}\right)$ & 1.6E-03 & $2.5 \mathrm{E}-02$ & $2.8 \mathrm{E}-02$ & 3.0E-01 & 8.9E-06 & 3.4E-04 \\
\hline Chl.S (mg m $\left.{ }^{-3}\right)$ & $1 \mathrm{E}=03$ & 2.6E-02 & $3.9 \mathrm{E}-01$ & $1.9 \mathrm{E}-01$ & 1.2E-02 & $0 \mathrm{E}-02$ \\
\hline \multicolumn{7}{|c|}{ Station B } \\
\hline & $3.9 \mathrm{E}-01$ & $8.5 \mathrm{E}-01$ & 1.3E-01 & 5.8E-01 & $3.2 \mathrm{E}-01$ & 1.8E-01 \\
\hline Temp. $\left({ }^{\circ} \mathrm{C}\right)$ & 1.0E-03 & $9.8 \mathrm{E}-02$ & 4.0E-03 & 3.0E-03 & 3.6E-02 & 4.6E-02 \\
\hline Dens. $\left(\mathrm{kg} \mathrm{m}^{-3}\right)$ & $2.6 \mathrm{E}-01$ & $8.0 \mathrm{E}-01$ & 1.3E-01 & 4.2E-01 & 4.4E-01 & 1.8E-01 \\
\hline $\mathrm{O}_{2}\left(\mu \mathrm{mol} \mathrm{I} \mathrm{I}^{-1}\right)$ & 4.0E-02 & $7.4 \mathrm{E}-04$ & 5.5E-01 & 1.7E-07 & 2.8E-01 & $6.5 \mathrm{E}-01$ \\
\hline $\mathrm{O}_{2}$ (\% air sat.) & 1.7E-06 & 9.1E-01 & 3.8E-01 & 1.0E-04 & 5.1E-02 & $3.7 \mathrm{E}-01$ \\
\hline Chl. $\left(\mathrm{mg} \mathrm{m}^{-3}\right)$ & 3.3E-01 & $9.7 \mathrm{E}-02$ & 1.8E-04 & 42 & 2.1E-04 & 9.5E-03 \\
\hline Chl.S ( $\left.\mathrm{mg} \mathrm{m}^{-3}\right)$ & $6.4 \mathrm{E}-02$ & 2.1E-03 & 3.9E-02 & $E-05$ & 1.7E-02 & 2.1E-01 \\
\hline \multicolumn{7}{|c|}{ Station bc } \\
\hline Sal. (ppt) & 4.1E-02 & 5.3E-06 & $5.7 \mathrm{E}-02$ & 2.3E-01 & 1.3E-01 & $2.0 \mathrm{E}-01$ \\
\hline Temp. $\left({ }^{\circ} \mathrm{C}\right)$ & $3.1 \mathrm{E}-14$ & 3.6E-05 & 4.4E-04 & $6.6 \mathrm{E}-12$ & 2.4E-01 & 4.0E-03 \\
\hline Dens. $\left(\mathrm{kg} \mathrm{m}^{-3}\right)$ & $1.2 \mathrm{E}-02$ & 2.9 & 5.7E-02 & 23. & 1.4E-01 & -01 \\
\hline $\mathrm{O}_{2}\left(\mu \mathrm{mol} \mathrm{I} \mathrm{I}^{-1}\right)$ & $1.6 \mathrm{E}-07$ & $4.9 \mathrm{E}-13$ & 1.1E-01 & $3.6 \mathrm{E}-10$ & 4.5E-01 & 4.7E-02 \\
\hline $\mathrm{O}_{2}$ (\% air sat.) & 2.0E-01 & 3.6 & 8.1E-02 & 3.7E-11 & 1.0E-01 & 9.5E-01 \\
\hline Chl. $\left(\mathrm{mg} \mathrm{m}^{-3}\right)$ & 4.9E-03 & $6.9 \mathrm{E}-09$ & 2.6E-07 & 4.2E-08 & 1.2E-07 & 4.4E-04 \\
\hline Chl.S ( $\left.\mathrm{mg} \mathrm{m}^{-3}\right)$ & $2.2 \mathrm{E}-02$ & 7.7E-11 & 4.7E-03 & $9.5 \mathrm{E}-13$ & 2.8E-03 & $9.4 \mathrm{E}-02$ \\
\hline \multicolumn{7}{|c|}{ Station C } \\
\hline & $8.4 \mathrm{E}-03$ & 1.7E-01 & 4.0E-02 & -01 & 8.3E-02 & 7.8E-02 \\
\hline Temp. $\left({ }^{\circ} \mathrm{C}\right)$ & 3.3E-19 & $5.8 \mathrm{E}-09$ & 1.6E-04 & $5.8 \mathrm{E}-12$ & 6.0E-02 & 1.9E-02 \\
\hline Dens. $\left(\mathrm{kg} \mathrm{m}^{-3}\right)$ & $8.6 \mathrm{E}-04$ & $9.1 \mathrm{E}=02$ & 4.1E-02 & $6.8 \mathrm{E}-01$ & $9.8 \mathrm{E}-02$ & $8.6 \mathrm{E}-02$ \\
\hline $\mathrm{O}_{2}\left(\mu \mathrm{mol} \mathrm{I}^{-1}\right)$ & 1.1E-09 & $9.2 \mathrm{E}-15$ & 1.0E-01 & 2.4E-10 & 5.6E-01 & $3.9 \mathrm{E}-02$ \\
\hline $\mathrm{O}_{2}$ (\% air sat.) & 4.4E-04 & $5.5 \mathrm{E}-11$ & $6.1 \mathrm{E}-02$ & $1.5 \mathrm{E}-08$ & 1.1E-01 & 8.1E-01 \\
\hline Chl. $\left(\mathrm{mg} \mathrm{m}^{-3}\right)$ & 3.3E-01 & 7.8E-01 & 3.7E-06 & 5.3E-01 & 1.2E-08 & 3.8E-06 \\
\hline Chl.S $\left(\mathrm{mg} \mathrm{m}^{-3}\right)$ & $1.2 \mathrm{E}-05$ & 2.3E-01 & $5.0 \mathrm{E}-03$ & 3.3E-01 & $2.8 \mathrm{E}-03$ & $3.6 \mathrm{E}-03$ \\
\hline
\end{tabular}


Table 3. A: Slopes of the water column horizontal gradients of salinity, temperature, density, oxygen and chlorophyll for the four seasons. Grey text identifies slopes that are statistically not significant $(\mathrm{p}>0.05)$. Chl. (B) lists values for the chlorophyll concentration in the boundary layer (0-1 $\mathrm{m}$ above seafloor). B: Statistical evaluation of the changes in horizontal gradients between seasons.

\begin{tabular}{|c|c|c|c|c|c|c|c|c|c|c|c|c|}
\hline A & & Winter & & & Spring & & & Summ & & & Fall & \\
\hline Parameter & Slope & $r^{2}$ & $p$ & Slope & $r^{2}$ & $p$ & Slope & $r^{2}$ & $p$ & Slope & $r^{2}$ & $p$ \\
\hline Salinity & 0.24 & 0.41 & $5.9 \mathrm{E}-02$ & 0.46 & 0.68 & $1.4 \mathrm{E}-02$ & 0.39 & 0.58 & $2.4 \mathrm{E}-02$ & 0.28 & 0.64 & 1.7E-02 \\
\hline Temp. & 0.05 & 0.19 & 1.8E-01 & -0.09 & 0.71 & 1.1E-02 & 0.00 & 0.01 & 7.8E-01 & 0.10 & 0.25 & 1.3E-01 \\
\hline Density & 0.18 & 0.42 & 5.4E-02 & 0.39 & 0.70 & 1.1E-02 & 0.32 & 0.62 & 2.0E-02 & 0.22 & 0.69 & $1.2 \mathrm{E}-02$ \\
\hline $\mathrm{O}_{2}$ Sat & -0.25 & 0.87 & $2.6 \mathrm{E}-03$ & -0.30 & 0.83 & 4.0E-03 & -0.70 & 0.95 & $6.5 \mathrm{E}-04$ & -0.19 & 0.55 & $2.8 \mathrm{E}-02$ \\
\hline $\mathrm{Chl}$ & -0.10 & 0.28 & 1.1E-01 & -0.10 & 0.41 & 5.7E-02 & -0.07 & 0.11 & 3.0E-01 & -0.42 & 0.13 & 2.5E-01 \\
\hline Chl (B) & -0.21 & 0.85 & $2.5 \mathrm{E}-02$ & -0.12 & 0.52 & 1.7E-01 & -0.19 & 0.81 & 3.7E-02 & -0.27 & 0.70 & 7.9E-02 \\
\hline B & Winter & Winter & Winter & Spring & Spring & Summer & & & & & & \\
\hline & Spring & Summer & Fall & Summer & Fall & Fall & & & & & & \\
\hline & $p$ & $p$ & $p$ & $p$ & $p$ & $p$ & & & & & & \\
\hline Salinity & 7.6E-02 & 2.1E-01 & 6.8E-01 & $6.2 \mathrm{E}-01$ & 1.0E-01 & 3.1E-01 & & & & & & \\
\hline Temp. & 3.6E-04 & 9.3E-02 & 4.7E-01 & 3.6E-05 & 8.1E-04 & 4.8E-02 & & & & & & \\
\hline Density & 3.3E-02 & 1.6E-01 & $6.2 \mathrm{E}-01$ & 4.5E-01 & $4.5 \mathrm{E}-02$ & 2.4E-01 & & & & & & \\
\hline $\mathrm{O}_{2}$ Sat & 3.2E-01 & $9.2 \mathrm{E}-09$ & 2.7E-01 & $4.2 \mathrm{E}-07$ & 8.6E-02 & 4.6E-08 & & & & & & \\
\hline Chl & 9.7E-01 & 7.3E-01 & 2.9E-01 & $6.8 \mathrm{E}-01$ & 2.9E-01 & 2.6E-01 & & & & & & \\
\hline Chl (B) & $6.2 \mathrm{E}-01$ & 8.0E-01 & 4.7E-01 & 8.3E-01 & 2.5E-01 & 3.7E-01 & & & & & & \\
\hline
\end{tabular}


Table 4. A: Slopes of the horizontal gradients of $\mathrm{NOx}, \mathrm{NH}_{3}, \mathrm{PO}_{4}, \mathrm{Si}(\mathrm{OH})_{4}, \mathrm{TN}, \mathrm{N} / \mathrm{P}$ in the surface water layer $(0-1 \mathrm{~m})$ for the four seasons. Grey text identifies slopes that are statistically not significant $(p>0.05)$.

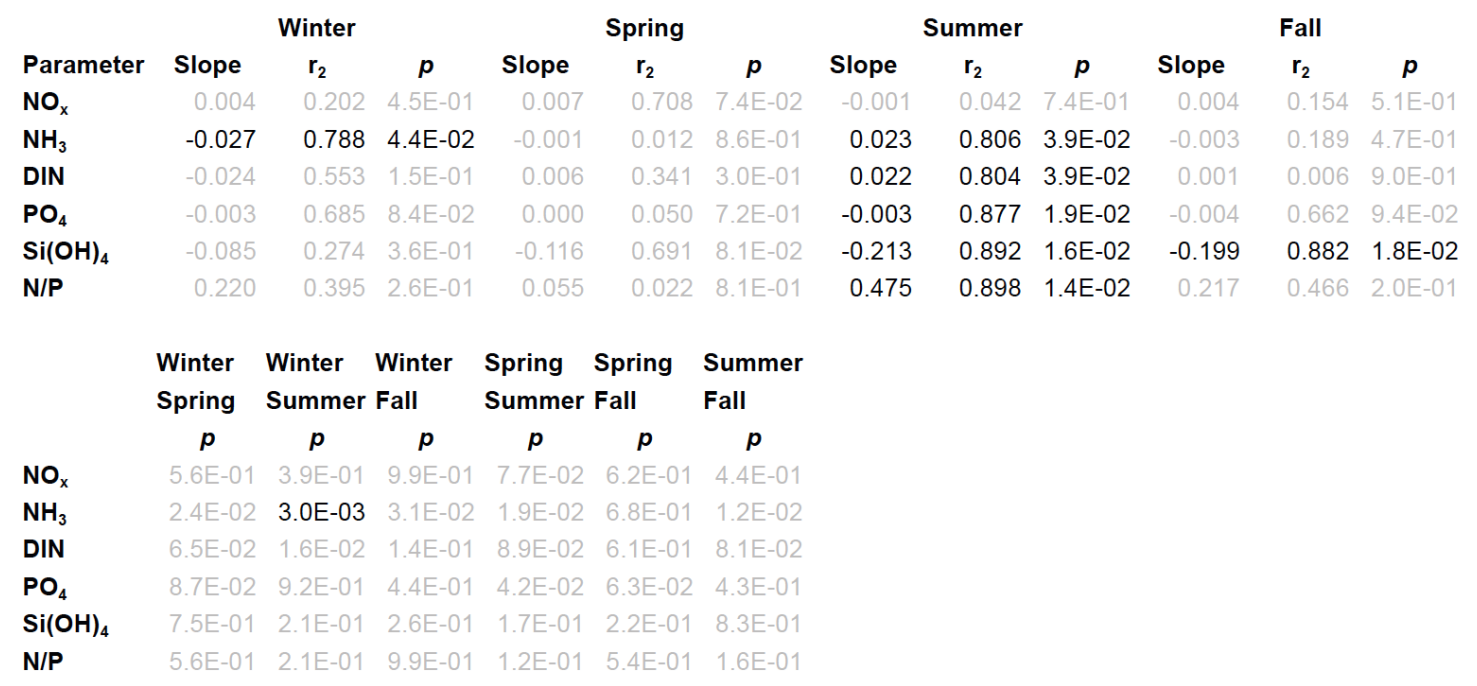


Table 5. Comparisons of gross primary production rates and respiration rates in terms of oxygen production and consumption from previous studies. "SD" columns denote 1 standard deviation for the preceding column's parameter.

\begin{tabular}{|c|c|c|c|c|c|c|c|c|c|c|}
\hline Source & Date & Location & $\begin{array}{c}\text { Depth } \\
(\mathrm{m})\end{array}$ & $\mathrm{n}$ & $\begin{array}{c}\mathrm{GP} \\
\mathrm{P}\end{array}$ & $\begin{array}{l}\mathrm{SD} \\
\mathrm{mm}\end{array}$ & $\begin{array}{l}\text { Resp } \\
\text { O } \\
\mathrm{O}_{2} \mathrm{~m}^{-3} \mathrm{~h}^{-1}\end{array}$ & SD & $\begin{array}{l}\text { Chla } \\
\mathrm{mgm}^{-3}\end{array}$ & $\begin{array}{c}\mathrm{O}_{2} \\
\mathrm{mmolm}^{-3}\end{array}$ \\
\hline \multirow[t]{2}{*}{$\begin{array}{l}\text { Jiang et } \\
\text { al., } 2011 \\
\end{array}$} & $\begin{array}{l}\text { 31-Jun to } \\
\text { 5-Aug- } \\
2008\end{array}$ & Aodi, Taiwan & 4.5 & $\begin{array}{c}6 \\
\text { and } \\
9 \dagger\end{array}$ & 0.69 & 0.42 & 0.24 & 0.11 & 0.5 & 207 \\
\hline & $\begin{array}{c}4-J u n \text { to } \\
\text { 12-Jun } \\
2008\end{array}$ & $\begin{array}{c}\text { NanwanBay,T } \\
\text { aiwan }\end{array}$ & 3 & $\begin{array}{c}14 \\
\text { and } \\
25 \dagger\end{array}$ & 0.71 & 0.30 & 0.28 & 0.16 & & 212 \\
\hline \multirow[t]{4}{*}{$\begin{array}{c}\text { Williams } \\
1998^{\star *}\end{array}$} & $\begin{array}{c}\text { May } 1989 \\
\text { and Jun } \\
1991 \\
\end{array}$ & $\begin{array}{c}\text { NE Atlantic } \\
\text { Ocean }\end{array}$ & 10 & 29 & 0.44 & 0.08 & 0.28 & 0.25 & & \\
\hline & Sep-1994 & Arabian Sea & 10 & 7 & 0.42 & 0.17 & 0.40 & 0.08 & & \\
\hline & 1990-1993 & $\begin{array}{c}\text { Mediterranean } \\
\text { Sea } \\
\end{array}$ & 10 & 18 & 0.33 & 0.17 & 0.17 & 0.08 & & \\
\hline & Sep-1984 & $\begin{array}{c}\text { N central } \\
\text { Pacific }\end{array}$ & 10 & 5 & 0.06 & 0.02 & 0.05 & 0.08 & & \\
\hline $\begin{array}{c}\text { Gubelitet } \\
\text { al. } 2010^{* *} \\
\ddagger\end{array}$ & 2002-2006 & $\begin{array}{c}\text { Shore of Neva } \\
\text { Bay estuary, } \\
\text { Baltic Sea }\end{array}$ & 0.5 & 3 & 79 & & & & & $\begin{array}{c}\text { 30.2(Aug)- } \\
371 \text { (Jun) }\end{array}$ \\
\hline $\begin{array}{l}\text { Webster et } \\
\text { al. 2002* }\end{array}$ & $\begin{array}{l}\text { 17-Dec- } \\
1997\end{array}$ & $\begin{array}{l}\text { Lake Illawarra, } \\
\text { Australia, } 34 \\
\text { 30'S (brackish } \\
\text { lagoon) }\end{array}$ & 5 & & 0.34 & & & & 1.6 & 203 \\
\hline $\begin{array}{l}\text { Gutierrez- } \\
\text { Rodriguez } \\
\text { et al. } 2011 \\
* * *\end{array}$ & 2004-2005 & $\begin{array}{c}\text { Blanes Bay, } \\
\text { Mediterranean } \\
\text {, Spain }\end{array}$ & 20 & 31 & 0.30 & 0.10 & 0.16 & 0.10 & 0.54 & \\
\hline $\begin{array}{l}\text { Krause- } \\
\text { Jensen et } \\
\text { al. } 2012 \text { * } \\
{ }^{* *} \ddagger\end{array}$ & 1980-2008 & $\begin{array}{c}\text { Limfjorden, } \\
\text { Denmark, } \\
\text { nutrient- } \\
\text { replete basins }\end{array}$ & 4.6 & & 1.05 & & & & 5 & \\
\hline & 1980-2008 & $\begin{array}{l}\text { Limfiorden, } \\
\text { Denmark, } \\
\text { nutrient-rich } \\
\text { basins }\end{array}$ & 4.6 & & 1.52 & & & & 13 & \\
\hline $\begin{array}{l}\text { Sallonet } \\
\text { al. } 2011^{*} \\
{ }^{* *} \ddagger\end{array}$ & $\begin{array}{l}\text { Jun and } \\
\text { Jul } 2008\end{array}$ & $\begin{array}{c}\text { Amundsen } \\
\text { Gulf, Beaufort } \\
\text { Sea, Canada }\end{array}$ & 100 & & 0.05 & 0.03 & & & 0.89 & \\
\hline $\begin{array}{l}\text { Daneriet } \\
\text { al. } 2012 \text { * }\end{array}$ & Jan-07 & $\begin{array}{c}\text { Bay of } \\
\text { Collumo, } \\
\text { Chile, no } \\
\text { bloom }\end{array}$ & 10 & & 3.04 & 0.82 & 0.72 & 0.20 & 2 & \\
\hline & Feb-07 & $\begin{array}{c}\text { Bay of } \\
\text { Collumo, } \\
\text { Chile, bloom }\end{array}$ & 10 & & $\begin{array}{c}19.2 \\
7 \\
\end{array}$ & 9.07 & 1.86 & 1.07 & 6.3 & \\
\hline $\begin{array}{l}\text { Hargravee } \\
\text { t al. } 1983 \text { * }\end{array}$ & $\begin{array}{c}\text { summer } \\
1979\end{array}$ & $\begin{array}{l}\text { Peck's Cove, } \\
\text { Bay of Fundy, } \\
\text { Canada }\end{array}$ & 0.5 & 4 & 1.24 & 0.68 & $\underset{* \star}{0.29}$ & & 2.75 & \\
\hline & $\begin{array}{c}\text { summer } \\
1979\end{array}$ & $\begin{array}{l}\text { Minas Basin, } \\
\text { Bay of Fundy, } \\
\text { Canada }\end{array}$ & 0.5 & 3 & 0.77 & 0.26 & & & 1.13 & \\
\hline $\begin{array}{l}\text { Burford et } \\
\text { al. } 2012 \text { ** } \\
\ddagger\end{array}$ & Dec-08 & $\begin{array}{c}\text { Buffalo Creek, } \\
\text { Darwin, } \\
\text { Australia }\end{array}$ & 1.6 & 3 & 4.75 & 3.65 & & & 90 & 90.6 \\
\hline & $\begin{array}{c}\text { Oct } 07 \\
\text { and Mar } \\
08\end{array}$ & $\begin{array}{c}\text { Myrmidon } \\
\text { Creek, Darwin } \\
\text { Australia }\end{array}$ & 4.6 & 6 & 0.18 & 0.11 & & & 2.68 & 163 \\
\hline
\end{tabular}




\begin{tabular}{|c|c|c|c|c|c|c|c|c|c|c|}
\hline & $\begin{array}{c}\text { Oct } 07 \\
\text { and Mar } \\
08\end{array}$ & $\begin{array}{c}\text { Reference } \\
\text { Creek, Darwin } \\
\text { Australia }\end{array}$ & 4.6 & 6 & 0.21 & 0.03 & & & 2.83 & 163 \\
\hline \multirow[t]{2}{*}{$\begin{array}{l}\text { Chen et al. } \\
2000^{* * *} \ddagger\end{array}$} & 1993-1994 & $\begin{array}{c}\text { Offshore } \\
\text { Louisiana, } \\
\text { beyond } \\
\text { continental } \\
\text { shelf }\end{array}$ & $0-200$ & & 0.03 & & & & & \\
\hline & 1993-1994 & $\begin{array}{l}\text { Surface layer } \\
\text { depth }<25 \mathrm{~m} \\
\text { Louisiana } \\
\text { Coast }\end{array}$ & $0-25$ & 764 & 0.14 & 0.13 & & & $0.1-5.0$ & \\
\hline $\begin{array}{l}\text { Wanninkh } \\
\text { of et al. } \\
1997^{\star *}\end{array}$ & Apr-96 & W FL Shelf & & 27 & 0.14 & 0.4 & 0.06 & & 0.3 & \\
\hline \multirow[t]{2}{*}{$\begin{array}{l}\text { Yates et } \\
\text { al. } 2007^{\star *}\end{array}$} & Oct-2003 & Tampa Bay & 0.5 & 4 & 15.5 & & 7.75 & & 5 & 190 \\
\hline & Mar-2000 & Florida Bay & 0.5 & 3 & 8.84 & & 4.42 & & $<5$ & 220 \\
\hline \multirow[t]{3}{*}{$\begin{array}{l}\text { Vargo et } \\
\text { al. } 1987^{*} \\
{ }^{* *} \ddagger\end{array}$} & 1980 & $\begin{array}{l}\text { West FL } \\
\text { Shelf, } \\
\text { nearshore }\end{array}$ & $<20$ & & 0.27 & & & & & \\
\hline & 1980 & $\begin{array}{c}\text { West FL } \\
\text { Shelf, offshore }\end{array}$ & $20-10 C$ & & 0.08 & & & & $<0.3$ & \\
\hline & 1980 & $\begin{array}{c}\text { West FL } \\
\text { Shelf, } \\
\text { nearshore } \\
\text { during bloom } \\
\text { event }\end{array}$ & 6.4 & & 1.83 & & & & 2.5 & \\
\hline \multirow[t]{3}{*}{$\begin{array}{l}\text { Murrell et } \\
\text { al. } 2009 \\
\end{array}$} & $\begin{array}{c}\text { summers } \\
2003 \\
2004 \\
\end{array}$ & $\begin{array}{c}\text { Shoals } \\
\text { Pensacola } \\
\text { Bay upper } \\
\text { water column }\end{array}$ & 0.7 & 7 & 0.66 & 0.27 & 0.48 & 0.16 & 6.9 & 206 \\
\hline & $\begin{array}{c}\text { summers } \\
2003 \\
2004\end{array}$ & $\begin{array}{c}\text { Channel: } \\
\text { Pensacola } \\
\text { Bay upper } \\
\text { water column }\end{array}$ & 1.125 & 9 & 1.04 & 0.47 & 0.74 & 0.30 & 9.0 & 224 \\
\hline & $\begin{array}{c}\text { summers } \\
2003 \\
2005\end{array}$ & $\begin{array}{c}\text { Channel: } \\
\text { Pensacola } \\
\text { Bay lower } \\
\text { water column }\end{array}$ & 3.375 & 8 & 0.35 & 0.37 & 0.44 & 0.33 & 4.6 & 120 \\
\hline \multirow[t]{2}{*}{$\begin{array}{l}\text { Del } \\
\text { Castillo et } \\
\text { al. 2000 * }\end{array}$} & Mar-95 & $\begin{array}{c}\text { Apalachicola } \\
\text { River transect, } \\
22 \mathrm{~km} \\
\text { offshore }\end{array}$ & & & 1.63 & & & & 1 & \\
\hline & Mar-95 & $\begin{array}{c}\text { Apalachicola } \\
\text { River transect, } \\
56 \mathrm{~km} \\
\text { offshore }\end{array}$ & & & 0.33 & & & & 0.5 & \\
\hline $\begin{array}{l}\text { Mortazavi } \\
\text { et al. } 2000 \\
* * * \neq\end{array}$ & 1993-1996 & $\begin{array}{l}\text { Apalachicola } \\
\text { Bay, Florida }\end{array}$ & 8 & & 1.13 & & & & 1.63 & \\
\hline $\begin{array}{l}\text { Hitchcock } \\
\text { et al. } 2000\end{array}$ & Apr-96 & $\begin{array}{l}\text { W FL shelf, a } \\
\text { little SE of K- } \\
\text { tower: } 29 \mathrm{~N} \text {, } \\
84 \mathrm{~W}\end{array}$ & 25 & & 0.33 & 0.75 & 0.21 & 0.5 & 1.8 & \\
\hline \multirow[t]{3}{*}{ This study } & $2008-2010$ & Site A & 5 & 15 & 1.87 & 1.02 & 0.99 & 0.38 & 8.88 & 225 \\
\hline & 2008-2010 & Site B & 10 & 11 & 1.72 & 0.53 & 0.96 & 0.62 & 5.67 & 227 \\
\hline & $2008-2010$ & Site C & 18 & 13 & 1.33 & 0.57 & 0.77 & 0.28 & 1.99 & 227 \\
\hline
\end{tabular}

* calculated from carbon, assumes a PQ of 1.3

** calculated from rate per day, assumes photosynthesis over 12 hours a day 
$\dagger$ first $\mathrm{n}$ is for GPP, second $\mathrm{n}$ is for respiration

$\ddagger$ calculated from depth-integrated data, average of $100 \mathrm{~m}$ if $>100 \mathrm{~m}$ 


\section{Figure legends}

Figure 1. A: Locations of the stations along the study transect. Bottom mounted instruments were placed at Stations A, B and C (black circles). Additional vertical water column profiling was done at Stations ab and bc (grey circles).B: Station mean water depth (open circles) and mean depth of the wave base (solid circles) with distance from shore. The wave base is defined as the depth at which the wave orbital water movement decreased to $\mathrm{e}^{-\pi} \approx 0.04$ or $4 \%$ of the surface value(Dean and Dalrymple, 1991 ) and is estimated as wavelength/2. Whiskers denote 1 SD.C: Apalachicola river discharge 20072011: Maximum March $800 \mathrm{~m}^{3} \mathrm{~s}^{-1}$, minimum August $180 \mathrm{~m}^{3} \mathrm{~s}^{-1}$, data from USGShttp://waterdata.usgs.gov/nwis/; black line indicates best fit $4^{\text {th-order }}$ polynomial function.

Figure 2. Seasonal means of water column profiles measured at the 5 stations along the transect during the study period (winter $\mathrm{n}=6$, spring $\mathrm{n}=10$, summer $\mathrm{n}=10$, and fall $\mathrm{n}=$ 5). All data from each season over the study period were averaged within each meterdepth bin. The official end dates of the respective seasons (solstice or equinox) were used to assign data to seasons.

Figure 3. A: Average horizontal gradients measured at the 5 stations along the transect (winter $n=6$, spring $n=10$, summer $n=10$, and fall $n=5$ ). Seasonal trends are shown for the surface layer (grey triangles, 0-1 m), mid water layer (white circles) and boundary layer (black squares, 0-1 m above seafloor). B: gradient change graphs depict the slope of 
least squares linear regressions in the measured parameters over distance from shore in $\mathrm{km}$ between seasons for surface, mid, and bottom water. The error bars depict 1 standard deviation.

Figure 4. Slopes of the average annual vertical oxygen profiles along the transect. The grey area depicts the depth range $(<8 \mathrm{~m})$ where the wave orbital motion was strong enough to resuspend the sediment. White circles represent shallower stations. Black circles represent deeper stations (difference between slopes: standard error:0.057, $\mathrm{t}=$ $1.3967, \mathrm{df}=27: \mathrm{p}=0.1738)$

Figure 5. Spatial and temporal distribution of average Chla concentrations integrated over the entire water column along the transect. Each horizontal layer presents measurements made in the year indicated on the y-axis. The dotted vertical helper lines indicate an offshore bloom in the late winter (February, first dotted reference line on the left), a spring bloom in March/April with a maximum near the coast, an early summer maximum more offshore and a fall bloom in October/November.

Figure 6. Seasonal nutrient distributions in the surface water layer $(0-1 \mathrm{~m})$ along the transect. Black circles: DIN, grey circles $\mathrm{NH}_{4}{ }^{+}$, white circles: $\mathrm{NO}_{\mathrm{x}}$, black triangles: $\mathrm{PO}_{4}{ }^{3-}$, white diamonds: $\mathrm{Si}(\mathrm{OH}) 4$. The large symbols at the left side of each figure $($ at $\mathrm{km}=1)$ represent the respective nutrient concentrations in Apalachicola Bay, and for DIN and 
silicic acid scaled according to the right axes of the respective graphs (Apalachicola Bay data are from the Apalachicola Estuarine Research Reserve, available at http://cdmo.baruch.sc.edu).

Figure 7. Irradiation profiles measured on 28 July 2009 along the transect and associated average attenuation coefficients. Some measurements in the lower section of the profile at station $\mathrm{C}$ failed due to sensor contamination. Surface irradiation data from the Apalachicola Estuarine Research Reserve are available at http://cdmo.baruch.sc.edu.

Figure 8. Calculated average vertical and horizontal profiles of oxygen production and oxygen consumption during the study for a realistic irradiation of $200 \mu \mathrm{E} \mathrm{m}^{-2} \mathrm{~s}^{-1}$. The productivity rates shown are gross productivity. Top figure: Open circles: Station A, grey circles: Station B, black circles: Station C. Error bars are standard deviation. Station A n $=15($ bottom $n=8$ and surface $n=7)$, Station $B n=12($ bottom mid and surface $n=4)$, and Station $C \mathrm{n}=15$ (bottom mid and surface $\mathrm{n}=5$ ) Bottom figure: open circles: surface water, grey circles: mid water, black circles: bottom water.

Figure 9. Water column production/respiration ratios plotted for the four seasons. P/R ratios did not differ significantly between surface, mid water and bottom layers and seasons. The slopes of the regression lines were statistically significant except for fall 
(Winter: $\mathrm{df}=18, p=0.0002, p<0.05$, Spring: $\mathrm{df}=12, p=0.0231, p<0.05$, Summer: $\mathrm{df}=$ $15, p=0.0060, p<0.05$, Fall: $\mathrm{df}=10, p=0.7718, p>0.05)$.

Figure 10. Oxygen production in water samples collected in July 2011 at Stations A (white triangles), B (grey circles) and C (black squares) exposed to different irradiance intensities. Production rates were binned for irradiance intensities $<500 \mu \mathrm{E} \mathrm{m}^{-2} \mathrm{~s}^{-1}, 500$ $1,000 \mu \mathrm{E} \mathrm{m}^{-2} \mathrm{~s}^{-1}$, and $>1,000 \mu \mathrm{E} \mathrm{m}^{-2} \mathrm{~s}^{-1}$. For all stations, $\mathrm{n}=15$ of low irradiance, $\mathrm{n}=6$ for mid-irradiance (except for surface water from Stations B and C, where $n=3$ ), and $n=$ 3 for high irradiance.

Figure $11 \mathrm{~A}$ and B: Relationships between oxygen and chlorophyll content of the water for A: the surface layers $(<3 \mathrm{~m}$, no surface layer trend at Station A) and B: subsurface layers $(>=3 \mathrm{~m}) . \mathrm{C}$ and D: Relationships between oxygen and chlorophyll content in the subsurface layers ( $>=3 \mathrm{~m})$ at Stations A (white triangles), ab (black triangles), B (grey squares), bc (grey circles), and C (black circles) for C: Winter and D: Summer. Note different $Y$-axes in all graphs.

Figure 12. Primary production estimates for the entire water column (black squares, right axis), and surface (white circles), mid-water (grey circles) and boundary layers (black circles) along the transect for a sunny day in July. The estimates are based on a $12 \mathrm{~h} \mathrm{light}$ period, the irradiance profiles shown in Fig. 7 and the irradiance/production relationships shown in Fig. 10. Error bars depict standard deviation of estimates based on minimum, average and maximum irradiance/production ratios. 


\section{$\underline{\text { Figures }}$}

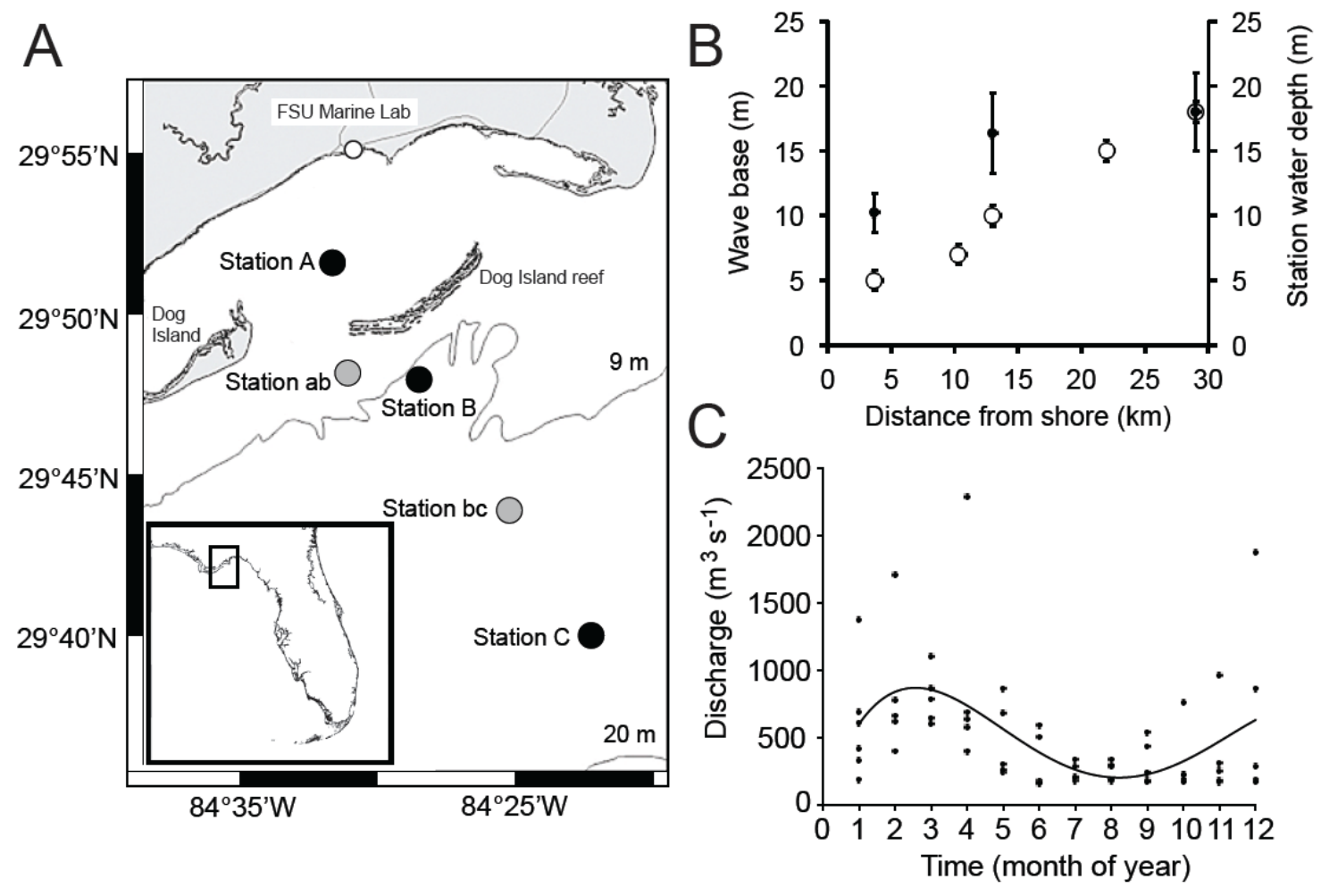

Figure 1, Santema et al. 
Salinity (ppt)
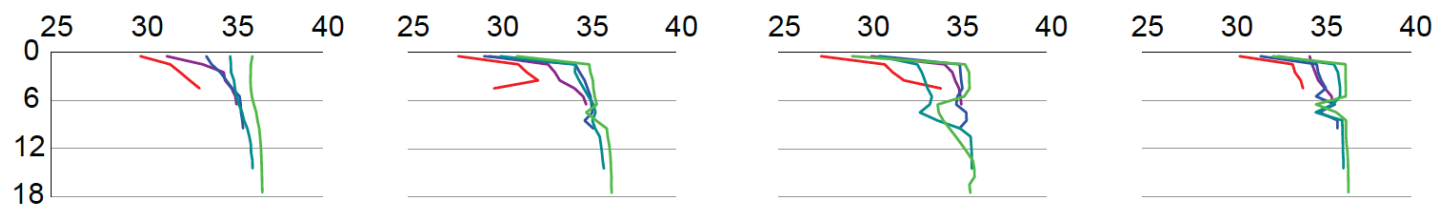

\section{Temperature (C)}
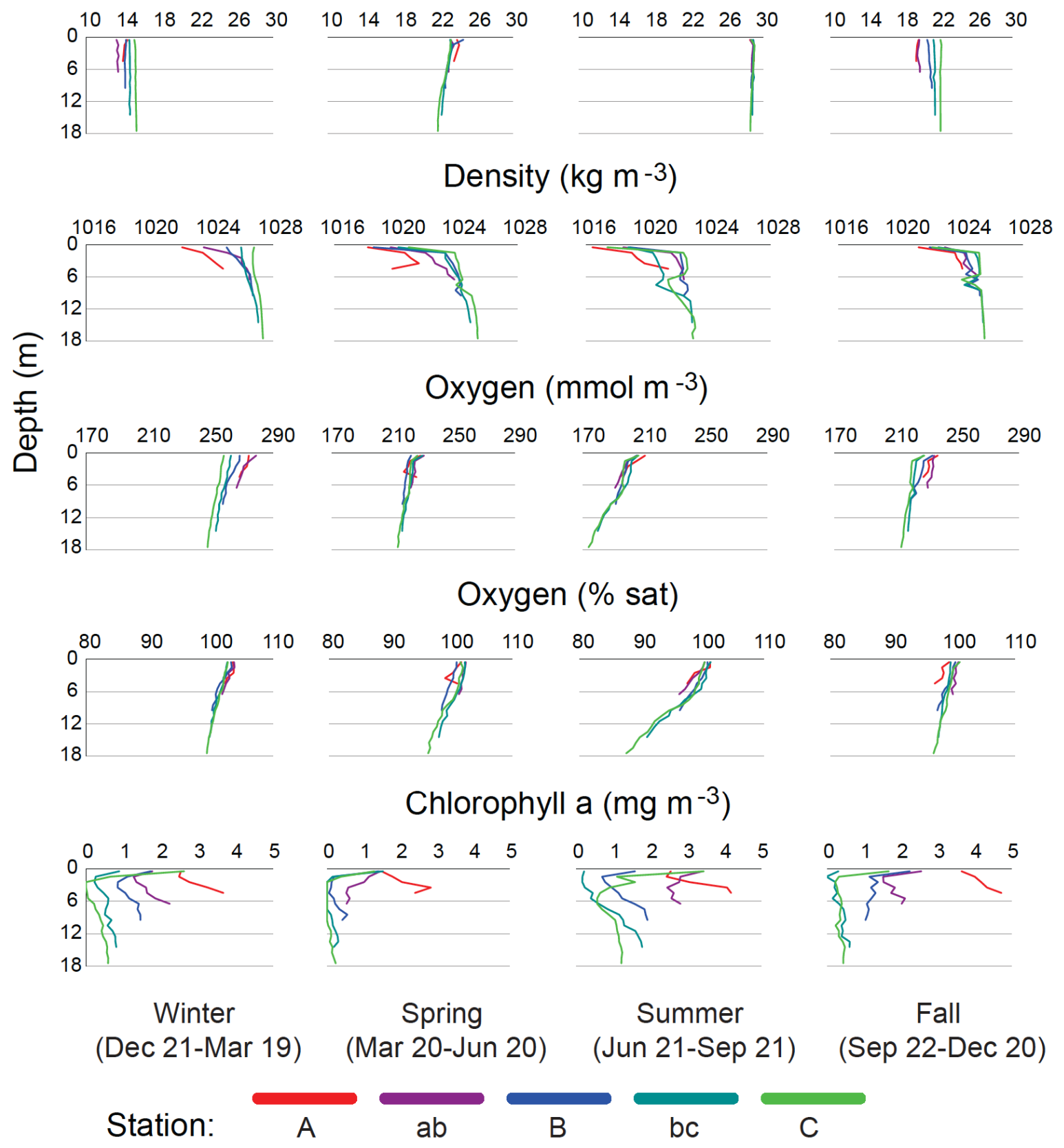

Figure 2, Santema et al. 


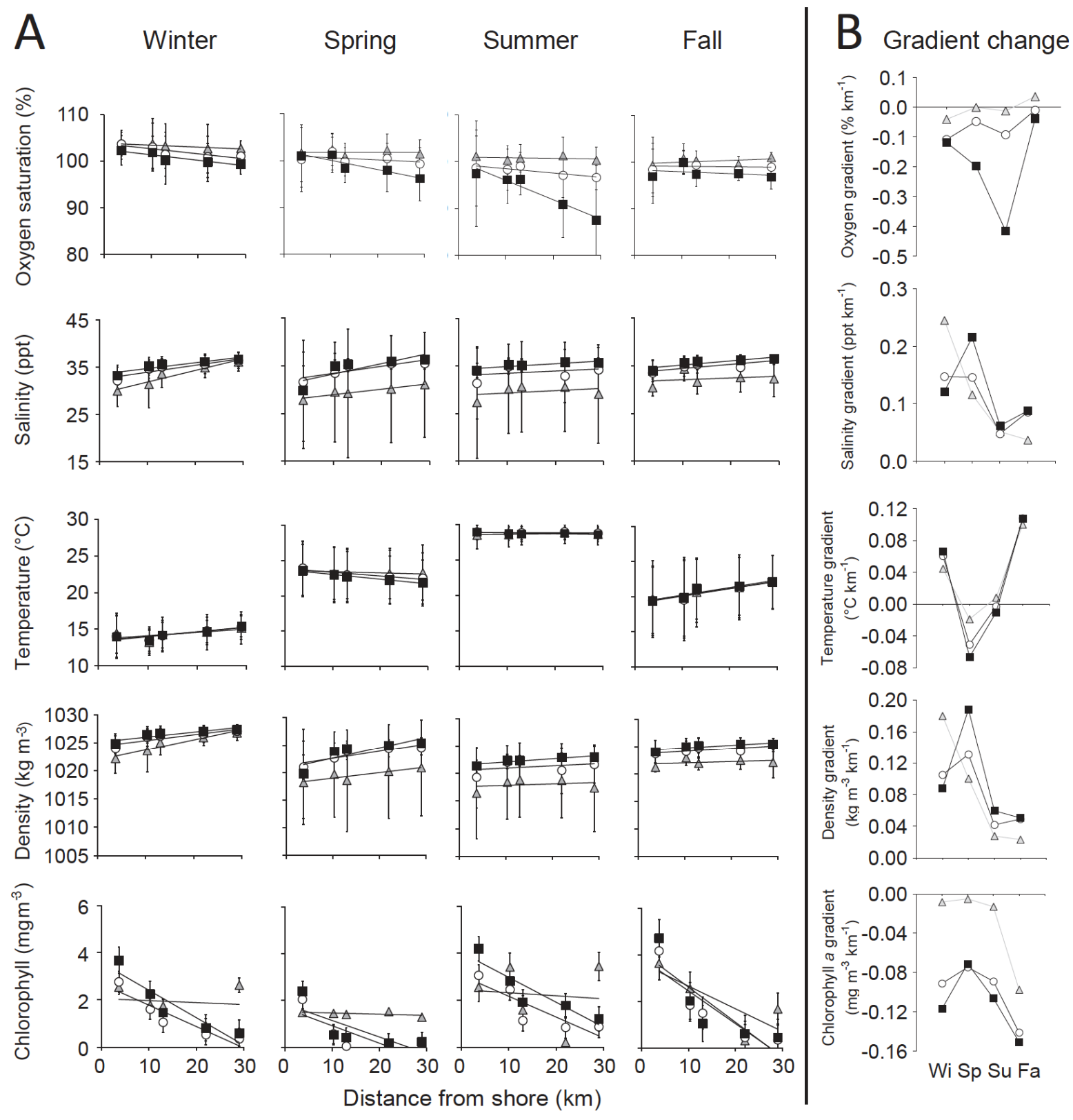

Figure 3, Santema et al. 
Distance from shore $(\mathrm{km})$

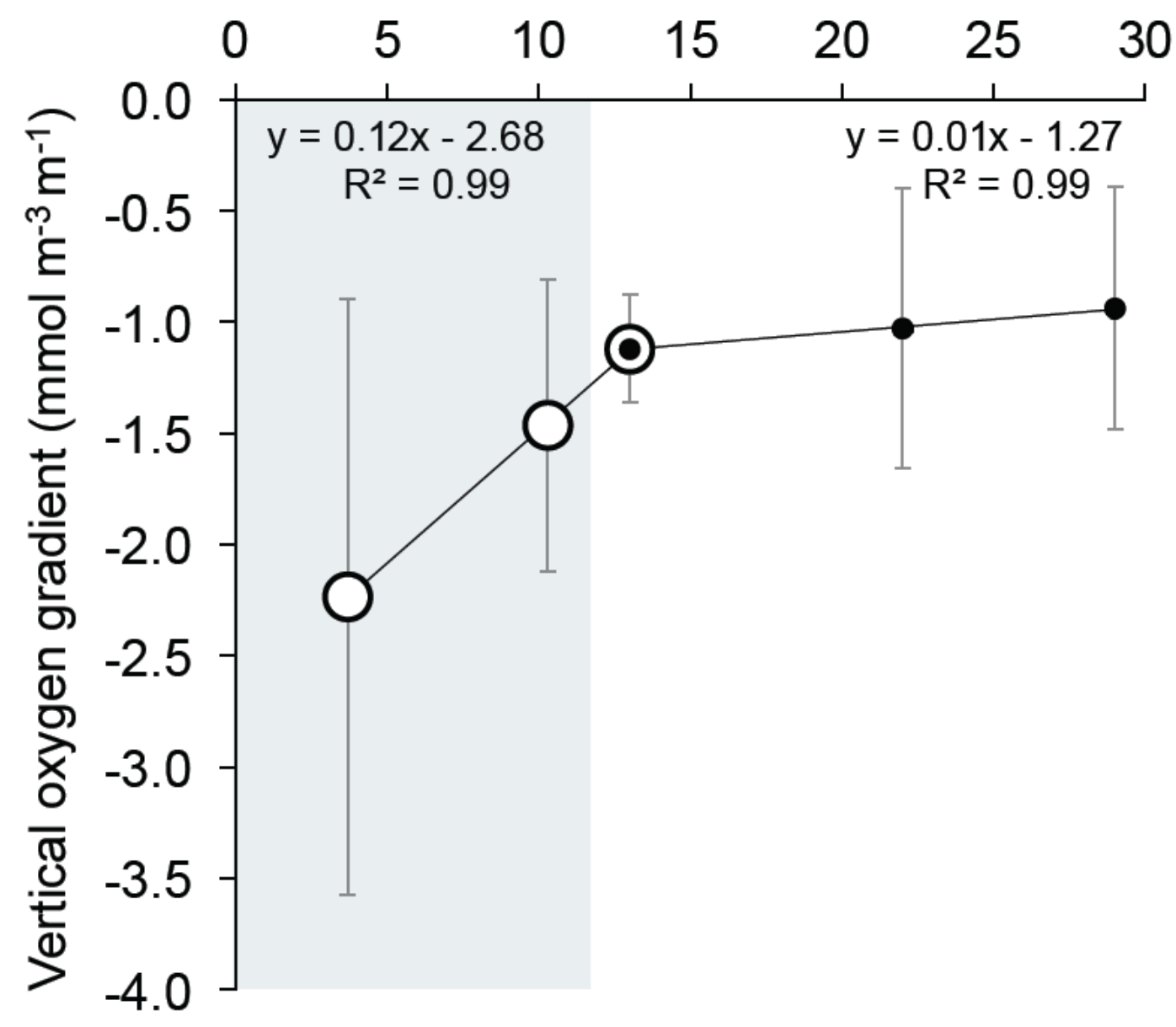

Figure 4, Santema et al. 
Chlorophyll a concentration $\left(\mathrm{mg} \mathrm{m}^{-2}\right)$

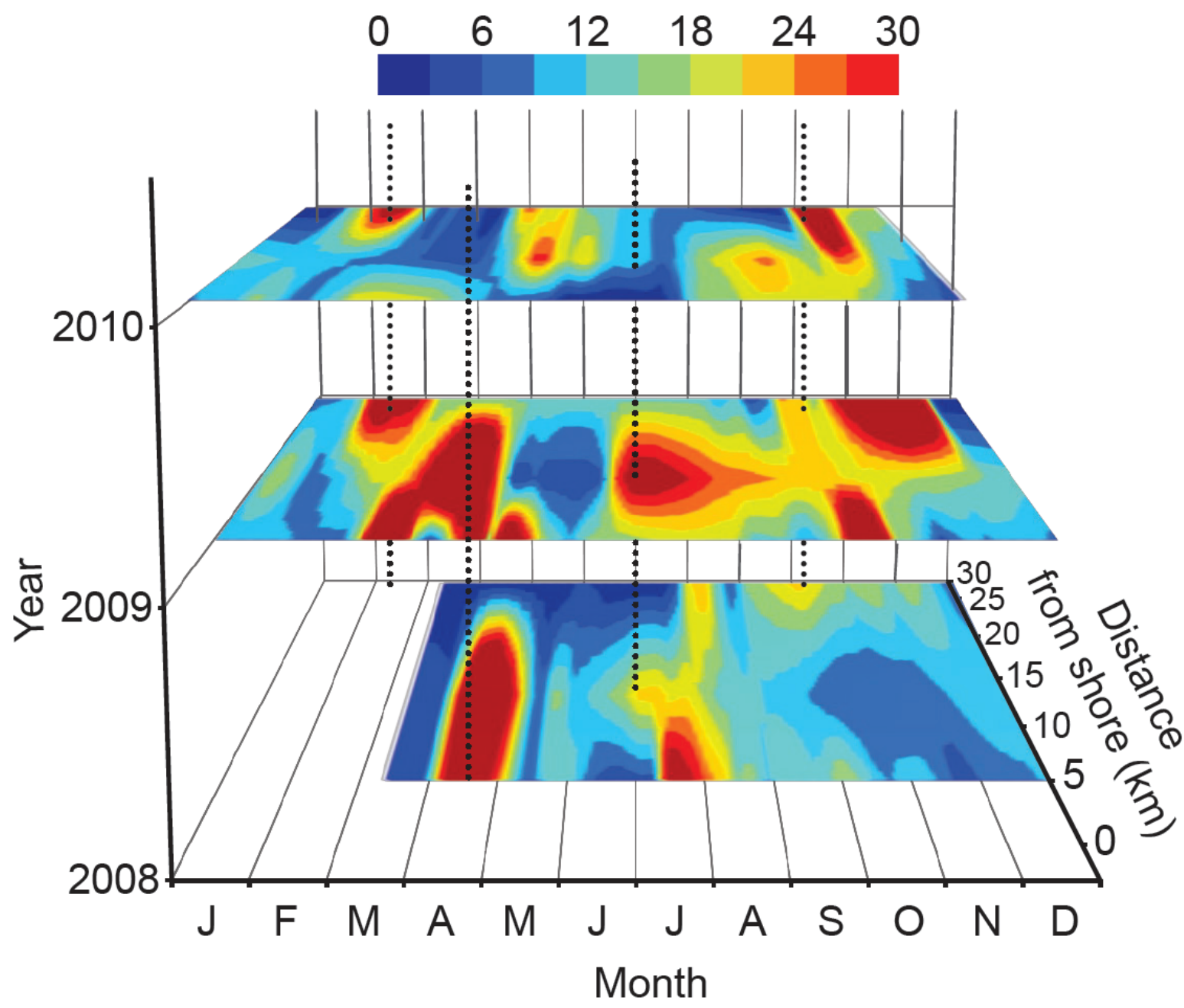

Figure 5, Santema et al. 


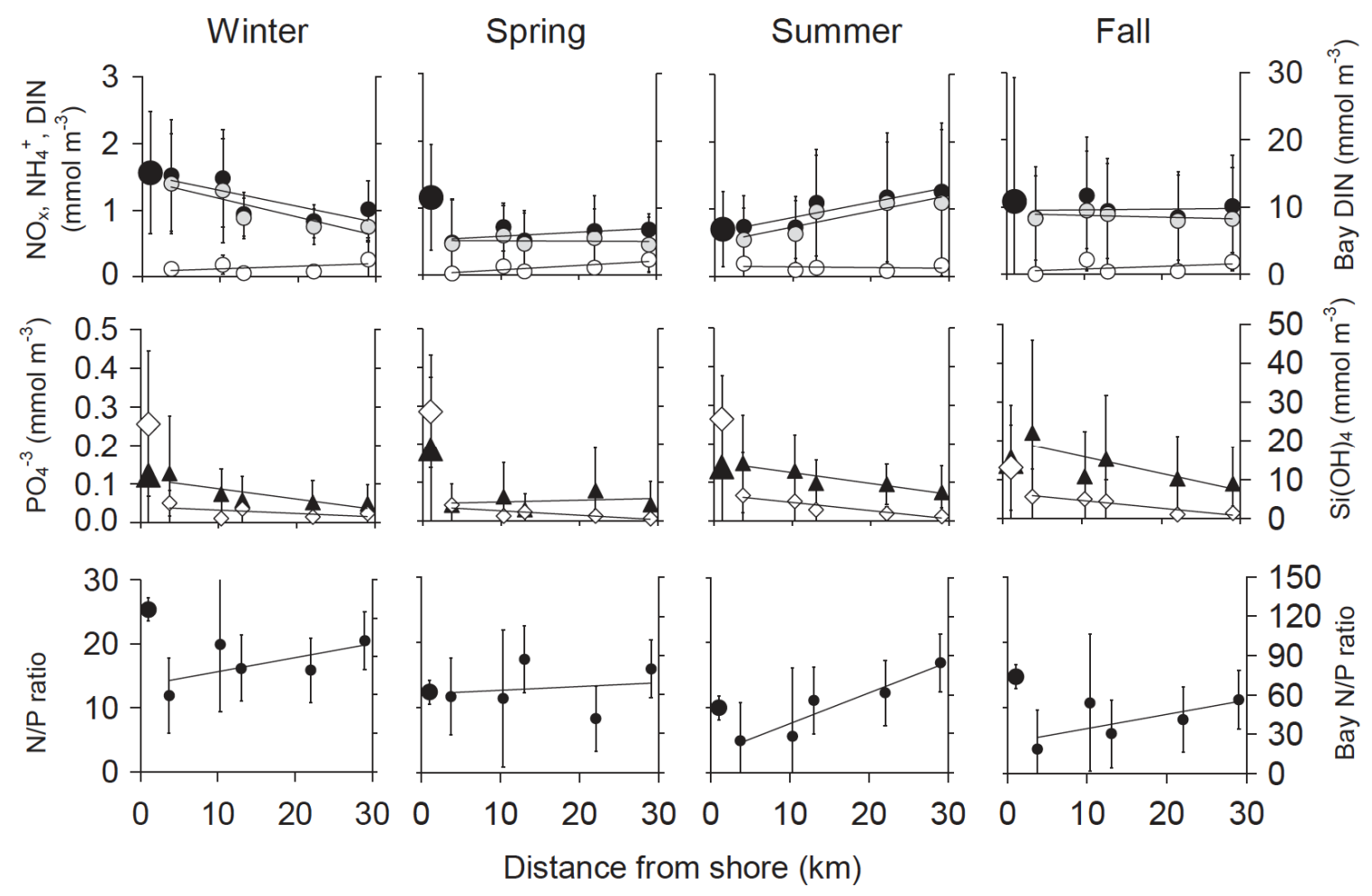

Figure 6, Santema et al. 


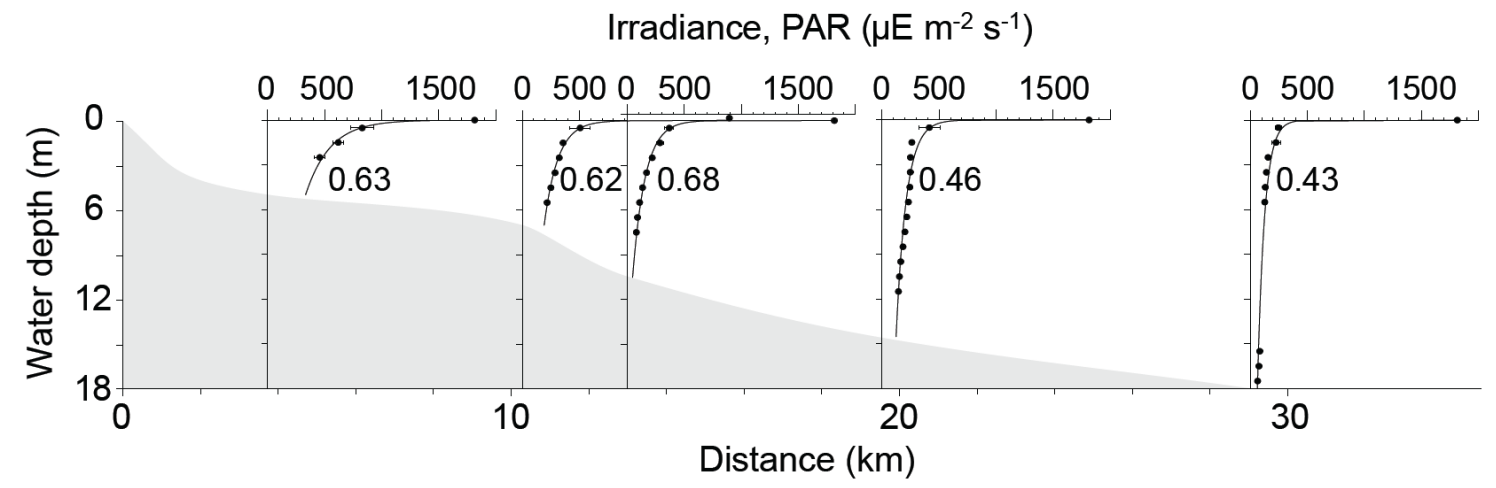

Figure 7, Santema et al. 


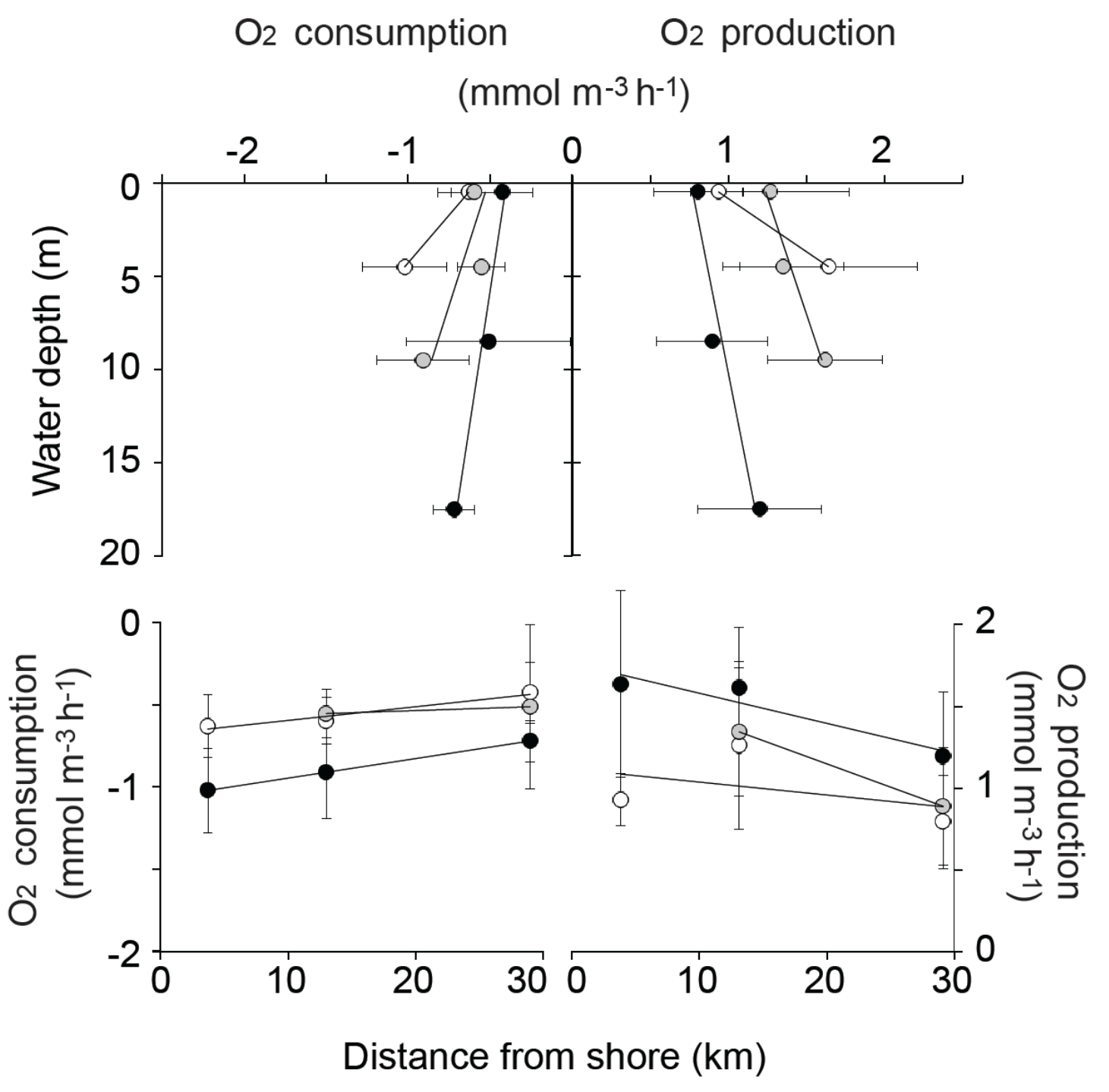

Figure 8, Santema et al. 


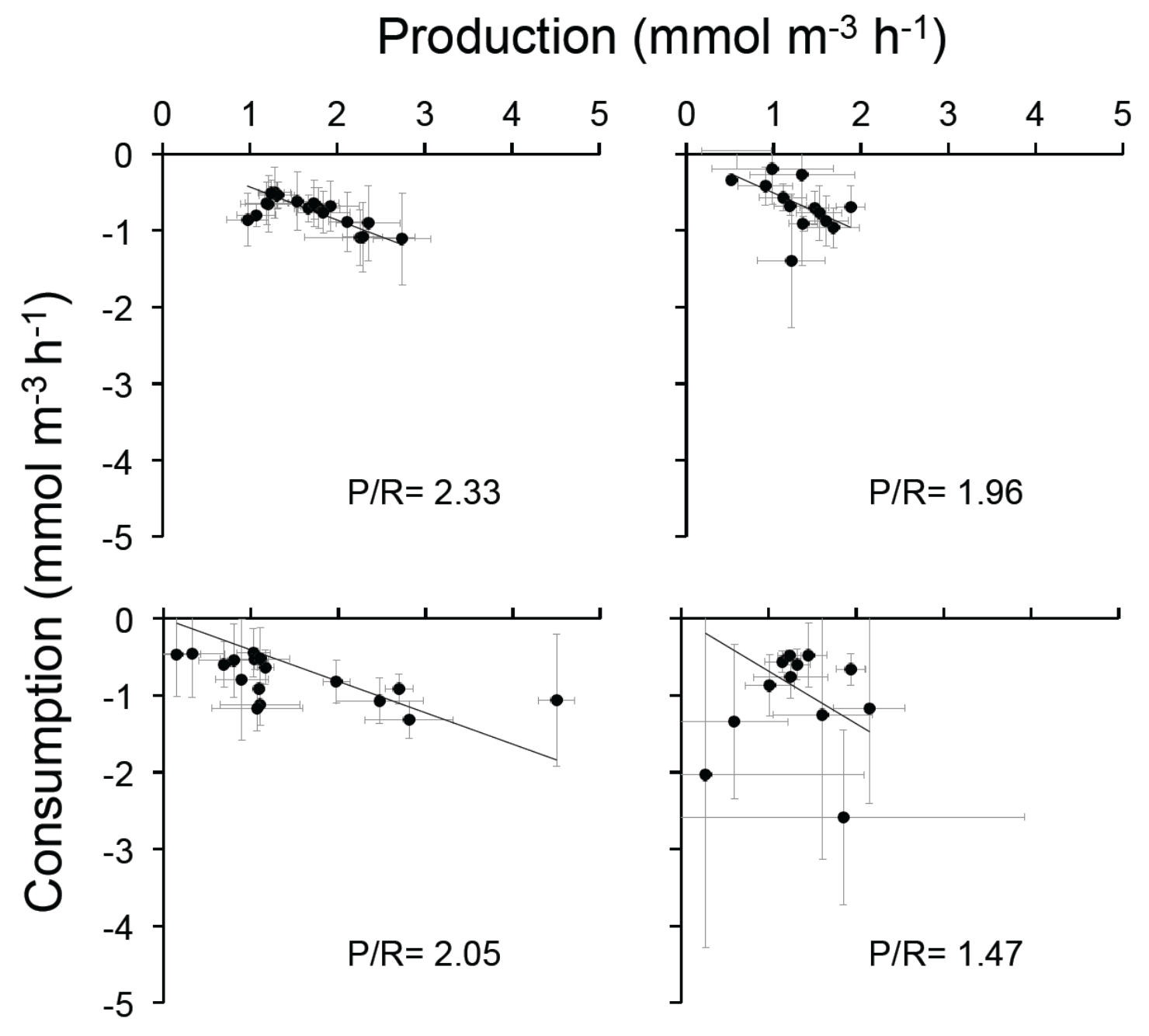

Figure 9, Santema et al. 


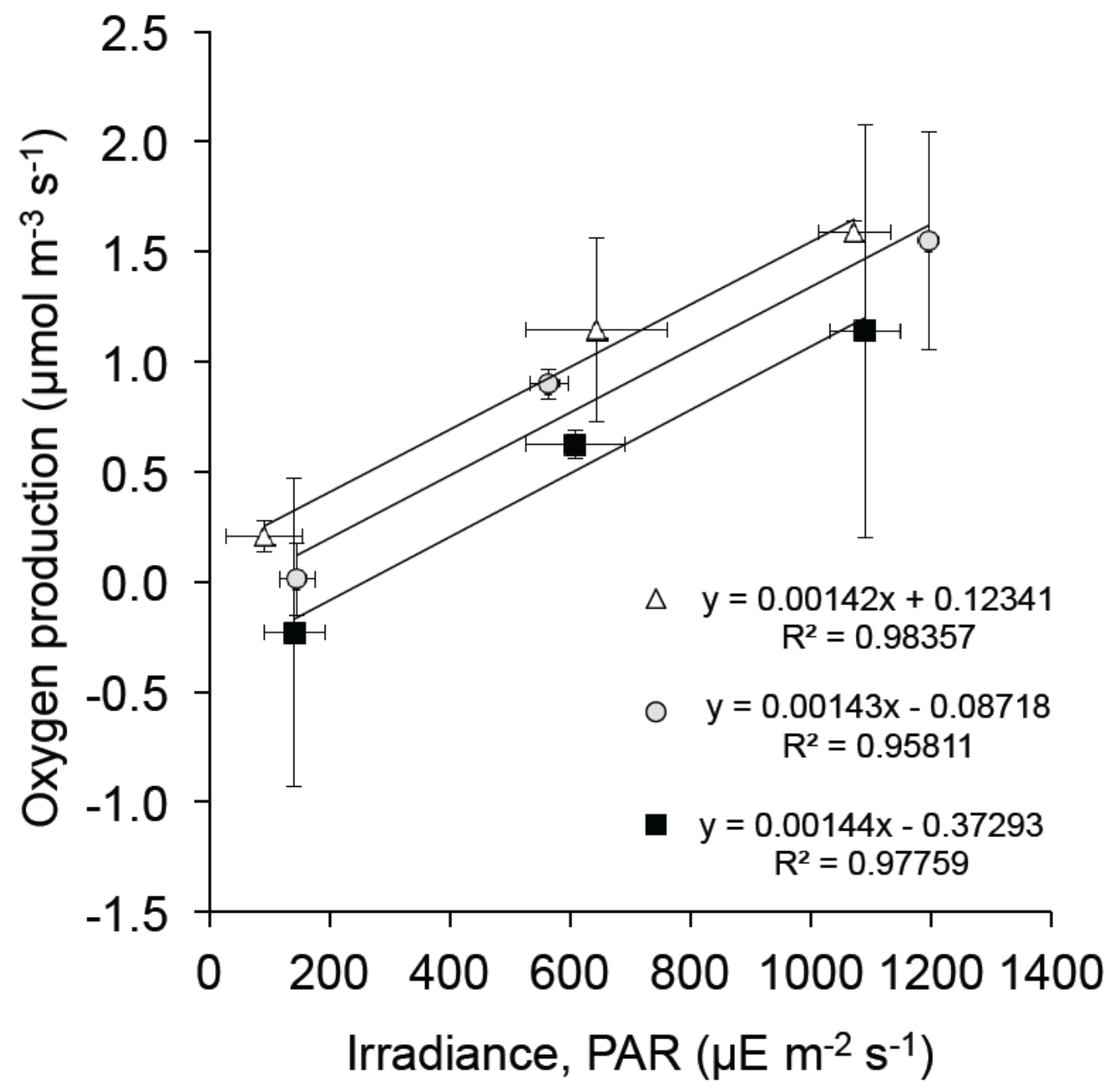

Figure 10, Santema et al. 

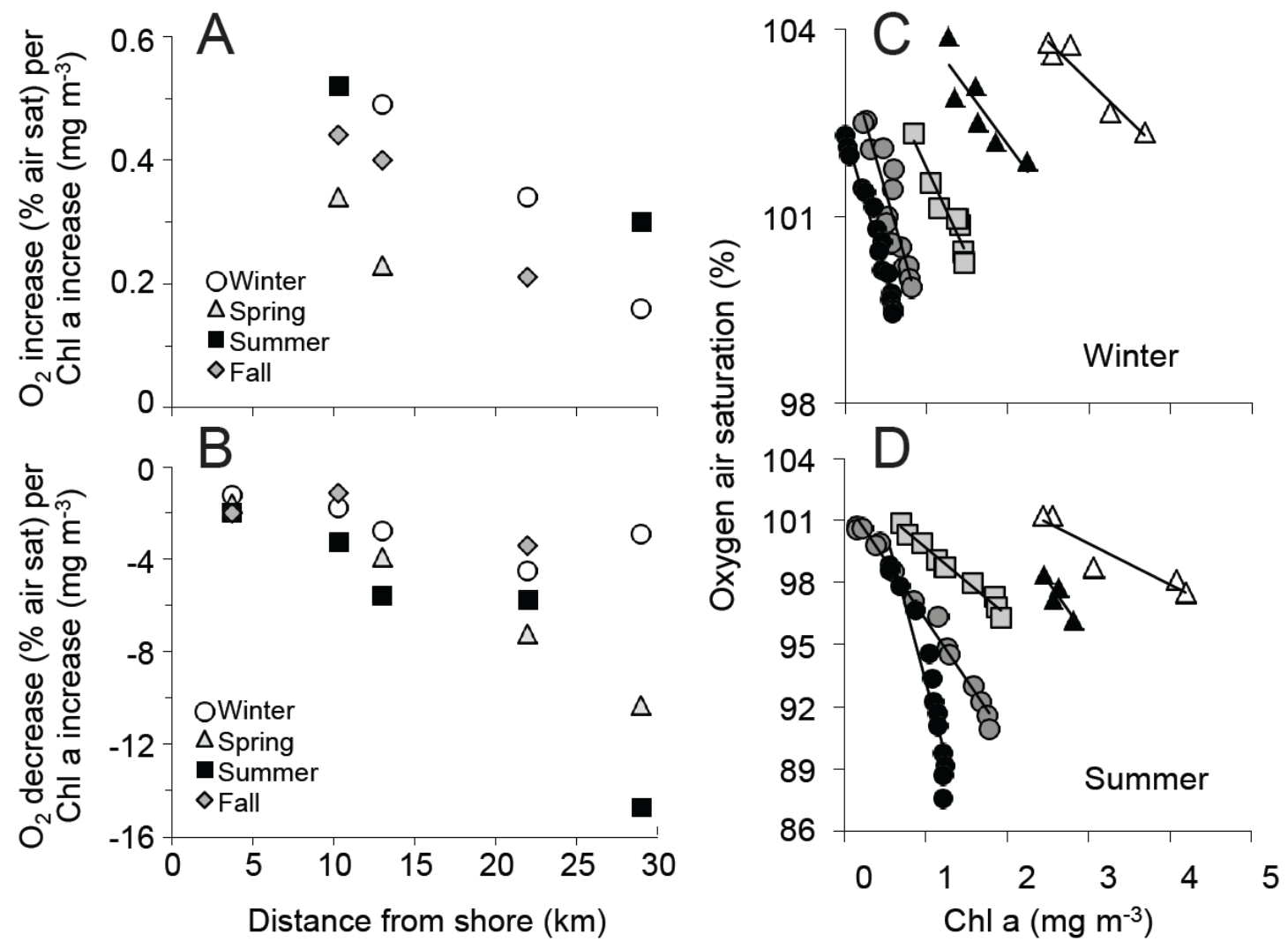

Figure 11, Santema et al. 


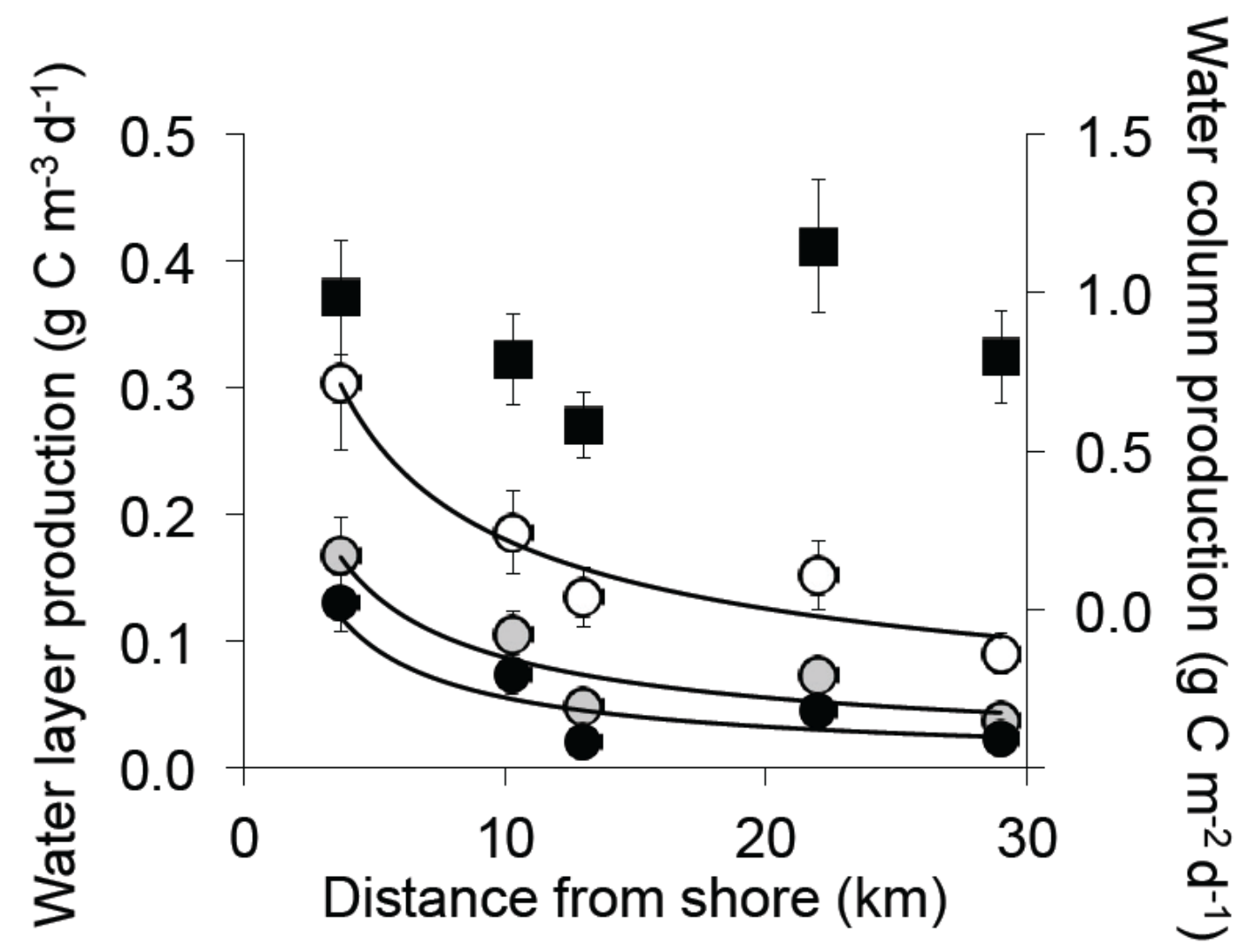

Figure 12, Santema et al. 